\title{
MODELI RADA SA OSOBAMA S INVALIDITETOM U CILJU PREVENCIJE MENTALNOG ZDRAVLJA
}

\section{Sažetak}

Jedan od značajnijih pokazatelja civiliziranog druśtva je stvaranje poticajnog okruženja za socijalnu pravdu i briga o osobama sonesposobljenjem. Odnos prema osobama sa invaliditetom mijenjao se uporedo s razvojem društva $i$ naučnom spoznajom. Sumerani (5000 god. p.n.e.) su nastojali da pomognu osobama sa onesposobljenjem tako što su ih liječili vjerskim ritualima na način da svećenik-liječnik sasluša bolesnika, otkriva grijeh, određuje prinošenje žrtve $i$ daje odredenu terapiju. Uspjeh ili neuspjeh terapije ovisio je o demonima. Human odnos prema osobama sinvaliditetom bio je i u starom Egiptu, gdje su osobe s invaliditetom bile pod posebnom zastitom bogova. „U Kini se smatralo da slijepi imaju razvijeno pamćenje i mišljenje, a neka od najranijih prikaza ljudskih prava mogu se naći u tekstovima indijskih Veda. Ideje dostojanstva, slobode, jednakosti i pravde javljaju se još u grčkoj filozofiji“" (Zovko, 1999:5). Od kamenog doba (XIII do IV milenijuma pr.n.e) pa sve do danas negativan stav drustva prema osobama sa invaliditetom se sporo mijenjao. Prema ruskom psihologu Vigotskom (1978), on je odreden društvenim $i$ historijskim kontekstom koji možemo podijeliti u tri razdoblja: Historijski gledano, kroz ova tri razdoblja riješene su mnoge dileme o uzrocima nastanka bolesti kao $i$ o ostvarivanju djelomicnih prava osoba sa onesposobljenjem. Međutim, još uvijek su izražene negativnosti u ponašanju $i$ stavovima zajednice, koje su usmjerene protiv osoba sa invaliditetom $i$ osporavanje njihovih prava na ravnopravno sudjelovanje u svim oblicima socijalnog života. Stoga, s pravom možemo reći da je, osim predrasuda $i$ stereotipa prema osobama sa invaliditetom, prisutna i diskriminacija.

Ključne riječi: inkluzija, mistično razdoblje; razdoblje aziliranja i razdoblje socijalne integracije.

${ }^{1}$ Islamski pedagoški fakultet u Bihaću. 


\section{Mistično razdoblje}

Prvo ili tzv. mistično razdoblje predstavlja doba antike koje obuhvata grčko-rimski stari vijek (XII-VIII stoljeće p.n.e.) pa sve do početka srednjeg vijeka. Ovaj period je period primitivnog i krajnje nehumanog odnosa prema osobama sa invaliditetom. Oko IX stoljeća pr.n.e medicina je imala vrlo malo znanstvenih činjenica i uglavnom se oslanjala na praznovjerje, a bolest se smatrala kaznom bogova. Ovakvi stavovi su se bazirali na informacijama iz Biblije, odnosno Starog i Novog zavjeta, gdje je invaliditet smatran božijom kaznom. „Tada se vjerovalo da su ljudi stvoreni na božiju sliku i svi oni koji nisu posjedovali tjelesno savršenstvo, tj. ako se ne bi uklapali u tu sliku, smatrani su nesavršenim i zlim ljudima“" (Gleeson, 1999:160). U Sparti (XI - VIII stoljeće p.n.e.) odgoj je bio stvar države. Spartanski odgojni cilj bio je izgradnja osobe u vojničke svrhe, a odgoj je započinjao od sedme godine života. Djecu koja su bila slaba i kržljava, po odluci najstarijih u rodovskom savezu (fili), izlagali su u gori zvijerima ili su ih bacali u klanac planine Tajget" (Zovko, ibid). Atenjani (VI - V stoljeće p.n.e.) su za razliku od Spartaka imali demokratski oblik vlasti koji se izražavao u političkoj jednakosti svih slobodnih državljana pred zakonom. Odgoj je imao klasni karakter, a cilj mu je bio odgojiti dobre državljane primjerene karakteru trgovačke i vrlo kulturne atenske države. Osobe sa invaliditetom smatrane su nekorisnim za državu, a odnos prema njima je bio toliko krut da su samo rijetki preživljavali. Ako bi ostali živi, bili bi totalno zanemareni. „Novorođenu djecu ostavljali su u šumama ili na pustim mjestima da ih rastrgaju životinje“ (Žunić, 2001). Talmud (VI-III stoljeće p.n.e) daje veliko medicinsko znanje rabinima o zdravlju životinja, te znanje iz ginekologije i anatomije. Visoko shvatanje liječničke etike je imao veliki utjecaj na babilonsku medicinu. Ni učenje Talmuda nije promijenilo odnos prama osobama $s$ invaliditetom. Smatrane su naivnim i nevinim, tj. neiskvarenim i da im je dosuđeno „kraljevstvo nebesko“. „U antičkom Rimu dijete s intelektualnim teškoćama je bilo obilježeno i nepoželjno jer su smatrali da se rodilo zbog bijesa bogova. Samo zato što je rođeno s razvojnom poteškoćom, dijete je bilo osuđeno da umre, osim ako je bilo iz imućne porodice“ (Harris, 2006). Shodno ovakvom shvatanju, bila je i zakonski uređena legislativa u staroj Grčkoj po kojoj se takvo dijete uz saglasnost plemstva može i ubiti. 
U prvom razdoblju rimske historije djeca s invaliditetom su se mogla ubiti i očevom voljom.

U VI stoljeću p.n.e. javljaju se prvi filozofi pa se medicina odvaja od religije i postaje gotovo čisto naučna disciplina. Dolazi do spoznaje da bolest ne nastaje uslijed uticaja natprirodnih sila, već kao posljedica poremećaja u organizmu. Sveštenici i prvi doktori, osim ritualne terapije, primjenjuju i racionalnu. Ova praksa je bila prisutna sve do pojave Hipokrata (460377.god.p.n.e.), koji medicinsku praksu bazira na promatranju ljudskog tijela gdje za bolest traži racionalno objašnjenje. Hipokrat je kreirao medicinsku terminologiju i osnove hirurgije koja se koristila sve do 19 . stoljeća. Velika zasluga pripada mu i za opis bolesti u kojem za epilepsiju tvrdi da ona nosi pogrešan naziv - sveta bolest. Moralni odnos prema pacijentu je zadržan sve do danas, a očituje se u njegovoj liječničkoj etici.

Od Hipokratove smrti pa do osnivanja aleksandrijske škole imamo stagniranje u pogledu medicine, ali ne i u humanističkom odnosu prema čovjeku koji je obilježen radom Platona (427-348.god. p.n.e.) i Aristotela (384-322.god. p.n.e). Aristotel unapređuje pedagošku nauku sa svojom teorijom harmoničnog razvoja tijela, uma i morala. Antička Grčka osobe s fizičkim i intelektualnim nedostacima naziva idiotima jer je u tom periodu bila izražena težnja za savršenosti tijela i duha. Naime, u V stoljeću pr.n.e. visoko je cijenjen skladan fizički razvoj koji se ogledao u dopunjavanju tjelesne snage sa duhovnom kulturom i dopunjavanju tjelesne ljepote sa idealom tjelesnog duha tzv. kalokagatija (grč.kalos-lijep, grč.agatos-dobar). U Rimskom pravu (754. god p.n.e. - 565.god. nove ere) slijepi, gluhi i nijemi su mogli postati nasljednicima. Oni su mogli biti i nositelji ugovora uz poseban oblik starateljstva, tzv. Cura debilium personarum. Ovaj oblik starateljstva se odnosio i na druge osobe kao što su paralizovani, iznemogli od starosti ili bolesti. Formalizam rimskog prava zahtijevao je izgovaranje svečanih formula i određene geste za punovažnost nekih pravnih poslova, zato je određivan staratelj osobi sa onesposobljenjem koja je indirektno nadoknađivala nemogućnost ispunjenja formalnih zahtjeva. Punopravna sposobnost se ogledala u okviru sljedeća četiri prava:

- pravo na zaključenje punovažnog braka; 
- pravo na bavljenje trgovinom, odnosno, pravo da se zaključuju poslovi, stiče svojina i bude stranka u parnici;

- aktivno biračko pravo;

- pravo na počasti, odnosno, pasivno biračko pravo.

„Status familiae“ određivao je da li je neko svojevlasno lice ili je potčinjen autoritetu porodičnog starješine, da li živi po tuđem pravu i da li ima poslovnu sposobnost. Iako pojmovi pravne i poslovne sposobnosti nisu bili jasno izdiferencirani kroz historiju, ipak možemo da kažemo da lišavanje poslovne sposobnosti osoba sa invaliditetom, kao i njihovo stavljanje pod starateljstvo, imaju korijene u rimskoj pravnoj tradiciji. Julije Paul, rimski pravni pisac, kaže da „Furiosus nullum negotim contrahere potest” tj. duševno bolesna osoba, ne može zaključiti nikakav pravni posao. Zakon XII tablica je propisivao da „umobolnicima i rasipnicima“ treba oduzeti poslovnu sposobnost i staviti ih, u tom pogledu, pod specijalnu vrstu staranja tzv. curu“ (Beker, 2010:6). Najznačajniji rimski pedagoški teoretičar Mark Fabije Kvintilijan (42-118.god) u svojim radovima posvećuje pažnju djeci s teškoćama u razvoju. On studiozno pojašnjava didaktička načela rada i ističe neophodnost poznavanja djeteta kako bi se sa njim individualno postupalo.

\section{Razdoblje aziliranja ili segregacije}

Prema Vigotskom, razdoblje aziliranja započinje pojavom hrišćanstva, a naročito od IV stoljeća, kada se pod utjecajem širenja pismenosti, kulture i hrišćanskog morala važnost daje milosrđu, humanosti i etičnosti. U ranom srednjem vijeku invaliditet je vezivan za opsjednutost zlim duhovima. „Osobe s izrazitim fizičkim deficitima su bile izložene egzorcizmu i dovođene u vezu s vješticama koje su spaljivali na lomači ili su bile zaključane u zatvorima, štalama ili napuštenim kućama, dok su osobe koje su imale gubu bile prisiljene živjeti u izoliranim kampovima“" (Jaeger i Bowman 1999). Pod utjecajem religijskog učenja, odnos društva prema osobama s razvojnim poteškoćama počeo se bitno mijenjati. Judaizam, hrišćanstvo i islam počinju da propovijedaju milosrđe prema svim ljudima, pa i osobama s invaliditetom. „Crkva potiče bogate 
pojedince da ulažu u dobrotvorne svrhe, zagovara davanje novčanih priloga za azile ili utočišta u kojima su smještene nemoćne, siromašne i osobe s invaliditetom" (Rački, 1997: 38).

$\mathrm{Na}$ istoku, početkom ranog srednjeg vijeka, dolazi do izvjesnog napretka u razumijevanju prava i položaja bolesnih osoba. Godine 622. na Arabijskom poluostrvu odnos prema siromašnim, ženama i onesposobljenima se drastično mijenja dolaskom Muhammeda, s. a. v. s, čije učenje zadire u sva područja ljudskog života. Prije njegovog dolaska nije bilo nikakvih zakonika i stalnih sudija, a odluke su u velikoj mjeri zavisile od utjecaja plemstva koje je samostalno donosilo presude o životu ili smrti pojedinca. Ukidanje ove prakse, kao i niz drugih pravnih regulativa, uređeno je prvim pravnim komplementarnim ustavom na svijetu, tzv. Medinskim ustavom. „Ovaj ustav je uredio Muhamed, a. s, koji je okvirno formalno i pravno uredio ponašanje, dužnosti, prava i obaveze svih podanika i žitelja zemlje. Prvih 25 članova Ustava se odnose na muslimane, a drugih 27 na Židove i nemuslimane. U poglavlju za muslimane, u članovima 12A i 12B, 13, 14 i 15 se solidarnost spominje u okviru dobročinstva i pomaganja bespomoćnim i bolesnim osobama“ (Spahić, 1996:176). U XI i XII stoljeću osnivaju se institucije koje vode stalnu brigu i pružaju pomoć bolesnim, starim, osobama s invaliditetom, napuštenoj djeci i siromašnima. Radi se o bolnicama, azilima, sirotištima, katedralama, samostanima, domovima za siromašne itd. koji su obično bili građeni pored crkve, te su, kao takve, imale epitet Božije kuće, Božije milosnice, dobrotvori itd. „U XII stoljeću, pod uticajem islamskog istoka na kršćanski zapad posredstvom križarskih ratova, u Evropi dolazi do sistematskog otvaranja bolnica i sirotinjskih domova“" (Spahić, 1996:395).

U doba humanizma i renesanse (XIV-XVI stoljeće) javlja se slobodniji svjetovni odnos prema čovjeku i njegovoj individualnosti. Osobe $s$ invaliditetom postaju brigom bogatih pojedinaca, a kasnije i zajednice. Stvaranjem građanskog društva razvijaju se opća građanska prava i formiraju napredni pokreti koji zahtijevaju da se osobama s razvojnom ometenošću prizna pravo na rad i obezbijede uslovi u kojima će biti profesionalno osposobljeni za neko zanimanje. Time započinje odvajanje 
lica sa razvojnom ometenošću, što je za posljedicu imalo humanizaciju odnosa i veću društvenu zaštitu.

U XVI stoljeću dolazi i do pojave Jezuitskog reda, koji se temeljno razlikovao od srednjovjekovnih redova. Ovaj red je imao za cilj da zaštiti jedinstvo katoličke crkve kroz odgoj omladine. Za korekciju uspjeha i ponašanja učenika nisu korištene batine, nego poniženje koje duboko vrijeđa ličnost učenika. Odgoj i obrazovanje osoba sa invaliditetom su bili privilegija samo bogatih. „Jedan od pozitivnih primjera je primjer Pedra Ponca De Leona (1520-1584), koji je poučavao sinove španjolskog plemstva koji su imali oštećen sluh, kako bi bili sposobni naslijediti vlasništvo. Upotrebljavao je čitanje i pisanje upotrebljavajući jednoručnu abecedu" (Žunić, 2001:22).

Buržoasko društvo (XVII-XVIII stoljeće) donosi velike promjene u društvenom odnosu prema osobama sa invaliditetom. Jan Amos Komenski (1592-1670) u svom djelu Didactica magna -Velika didaktika, iznosi da se „od svakog djeteta dade izgraditi čovjek“. Jedan je od prvih koji je odgoj doveo u svijet šire javnosti. On razvija cjelovit program: Svakoga sve temeljito na svaki način poučiti (omnes omnia omnino). „Svakog je značilo: siromašne i bogate, plemenite i neplemenite, mladiće i djevojke, gospodu i sluge, sposobne i nesposobne. To je bio društveno-politički nečuveno smion, čak revolucionaran zahtjev" (Blankertz, 1982:35).

Godine 1620. J.P. Bonet je objavio prvu metodiku rada s gluhonijemim djetetom što se može uzeti kao početak rada u području specijalnog odgoja. John Locke (1632-1704), jedan od najvećih mislilaca spoznajnoteorijske pedagogije u Engleskoj, razlike u sposobnostima među ljudima djelomično izvodi iz nasljeđa, a djelomično iz anantomsko-fiziološke organizacije nervnog sistema i time pobija svoju tezu da se djeca rađaju kao prazne neispisane ploče "tabula rasa”. „U Parizu 1784. godine osnovana je prva javna škola za djecu s teškoćama u razvoju“ (Vukasović, 1994:307).

U Leipzigu 1788. i Beču 1799. godine formiraju se zavodi za smještaj gluhonijemih osoba. Analogno tome, dolazi do radnog i profesionalnog osposobljavanja i zapošljavanja osoba $s$ invaliditetom u posebnim, samo njima namijenjenim ustanovama i pogonima. Na polju medicine se prvi 
put razvija psihijatrija. Philippe Pinel (1745 - 1826) iz Pariza uvodi humanije metode u psihijatriju, skida lance, zalaže se za fizičko i moralno liječenje bolesnika. On provodi aktivnu terapiju, razlikuje melankoliju, maniju, delirij, demenciju i idiotiju. Njegov učenik Jean Esquirol (1772 1840) stvara modernu psihijatrijsku definiciju i klasifikaciju duševnih bolesti. Humani postupak prema duševnim bolesnicima provode Vincenzo Chiarugi (1759 - 1820) u Italiji i William Tuke (1732 - 1822) i John Conolly (1794 - 1866) u Engleskoj (tzv. no restraint system). Uprkos razvoju civilizacije i otvaranju specijaliziranih ustanova u XVIII stoljeću i dalje susrećemo različita gledišta prema osobama koja imaju poteškoće u razvoju, a posebno prema osobama koje imaju psihičke poremećaje. Naime, mješavina poganskih vjerovanja i crkvene kanonske medicine djelovala je na zdravstveno stanje duševno oboljelih isključivo preko molitvi i magijskih rituala. Halke, razne vrste lanaca za vezivanje, zatvaranje i batinanje pacijenta toljagama, pri čemu je pacijent obješen za noge o plafon, da bi se nečastive sile istjerale iz bolesnika, bili su svakodnevica manastirskih iscjelitelja. Tretmane ove vrste primjenjivali su se sve do 1839. godine.

Iako se humanizacija odnosa prema osobama $s$ onesposobljenjem iskazivala većom brigom društva, u XVIII stoljeću i dalje postoji diskriminacija ove populacije. Jedan vid diskriminacije je bio i putujući cirkus, tzv. „Putovanje s nakazama“ (eng. Travelling freak shows), gdje su osobe sa tjelesnim i mentalnim invaliditetom bile atrakcija na sajmovima u Europi i Sjevernoj Americi. Osobe s invaliditetom su smatrane irelevantnim u društvu, te su mnogi roditelji prodavali djecu vlasnicima cirkusa ili putujućim zabavnim parkovima.

U XIX stoljeću pitanje mentalne zaostalosti počelo se tretirati znanstveno, a za to su zaslužne prvenstveno medicina i psihologija. Prvi slučaj znanstvenog rješavanja tog problema zabilježen je u Francuskoj. Jean Marc Gaspard Itard (1774-1838) bavio se odgojem, tzv. divljeg dječaka Viktora, koji je u dobi od jedanaest godina nađen u šumi kraj Aveyrona 1798. godine. Nakon pet godina mukotrpnog rada Itard zaključuje da nije uspio, međutim, Francuska akademija znanosti nije Itardove rezultate smatrala neuspjehom već propuštenim odgojem Viktora u kritičnom periodu 
razvoja od njegove 3. pa do 7. godine života. Neki su mišljenja da je Viktor bio mentalno zaostao, te da je bilo nemoguće išta postići u odgojnom i obrazovnom segmentu. „Tada je postavljeno pravilo da se napredak mentalno zaostale djece ne može upoređivati s napretkom normalne djece, već s mentalno zaostalom djecom koja nisu obuhvaćena odgovarajućim odgojem“" (Furlan, 1991:114).

Francuski liječnik J.E.D. Esquirol već je 1838. godine počeo jasno razlikovati mentalna oboljenja od mentalne zaostalosti koju je označavao terminom idiotija. Stereotipija je bila prisutna i u naučnim krugovima. „Osnivač antropologijske škole P. Broce (1824-1880) i zastupnik kriminalne antropologije C. Lambrosa (1836-1910), pokušavaju dokazati postojanje posebnih vrsta ljudi, tzv. prirođenih zločinaca, koji se po anatomskim, fiziološkim i psihičkim oznakama razlikuju od običnih ljudi (položeno čelo, izbočene čeljusti, tupoća osjetnih organa, nedostatak osjetilnih i više čuvstva), a razlike objašnjavaju atavizmom, tj. nasljeđem instinkta i svojstva primitivnog čovjeka. Poroci roditelja i dalekih predaka terete djecu za njihove grijehe“ (Šimleša, 1993:43).

Osim humanijeg odnosa prema čovjeku, razdoblje aziliranja značajno je zbog promjene svijesti o nastanku bolesti koja prevazilazi stoljetno shvatanje metafizičke uzročnosti i daje pečat egzaktnim činjenicama koji se izvode iz prirodnih nauka. Pod utjecajem psihofizike i eksperimentalne psihologije razvija se i eksperimentalna pedagogija čiji su predstavnici: August Lay (1862-1926) i Ernest Meumann (1826-1915) u Njemačkoj, u Francuskoj Alfred Binet (1857-1911) i Édouard Séguin (1812-1880), u SAD Edward Thorndike (1874-1949) i Stanley Hall (1864-1924) u bivšoj Jugoslaviji Paja Radosavljević (1879-1958) i Ramiro Bujas (1879-1959). Većina predstavnika je ispitivala inteligenciju kod djeteta, tzv. testovima ili pokusnim zadacima. $\mathrm{Na}$ osnovu rezultata ispitivanja izrađivani su testovi prosječne nadarenosti, uspješnosti, kao i niz drugih koji ispituju inteligenciju, nesposobnost, darovitost. Ova praksa se zadržala sve do danas kako bi se ispitali neophodni kriteriji za upis u redovnu školu za čije pohađanje je potrebna potvrda o psiho-fizičkoj razvijenosti djeteta $\mathrm{i}$ rezultat testa inteligencije IQ iznad 65. 
Na razmeđu XIX i XX stoljeća u Italiji dolazi do formiranja novog nacionalnog identiteta u oblasti materijalnih i duhovnih tekovina. Jedna od njih je bila i Marija Montessori (1870-1953), ljekar i pedagog, koja je dala pečat naučnoj orijentaciji u shvatanju idiotizma koji je medicina posmatrala kao bolest. Filozofija Marije Montessori se ogledala u tome da se napredak djeteta s poteškoćama u razvoju može ostvariti strpljivim radom od faze obrazovanja mišića i nerva, preko obrazovanja čula do intelektualnog i moralnog obrazovanja. Period aziliranja je obilježen segregacijom jer je još uvijek vladalo shvaćanje da je invaliditet apsolutno stanje koje se ne može izmijeniti. „Opći socijalni i materijalni odnosi nisu dopuštali širu emancipaciju školovanja, radnog osposobljavanja, zapošljavanja i rada osoba s invaliditetom” (Žunić, 2001:25).

\section{Razdoblje socijalne integracije}

Sa razvojem prava kao temeljnih sloboda, javljaju se različiti modeli rada sa osobama s onesposobljenjem. Whittaker (1997) navodi tri modela koja su obilježila razdoblje socijalne integracije: medicinski model; model deficita; socijalni model. Ranih šezdesetih godina prevladava medicinski model, u kojem je prisutna klasifikacija, etiketiranje i segregacijski način školovanja. U cilju iznalaženja adekvatnih terapijskih intervencija u okviru medicinskog modela osamdesetih dolazi do pojave modela deficita koji liječenje usmjerava prema patološkom uzroku nastanka bolesti i utvrđuje posebnu potrebu i integraciju. Oba modela se zasnivaju na pristupu koji naročito akcentira liječenje. Kasnijim razvojem, devedesetih dolazi do pojave socijalnog modela kojim se nastoji prevazići različitost i segregacija. U ovom modelu prevladavaju prava, a ne prednosti i privilegije pojedinaca. Socijalni model je zasnovan na sredinskom faktoru, koji posmatra kako faktor iz okruženja utječe na sudjelovanje osobe $s$ onesposobljenjem u društvu. Svaki od ova tri modela predlaže različite pristupe u radu, npr. kako intervenirati, kako spriječiti invalidnost i kako utvrditi stepen društvene odgovornosti. Ishodišni pristup određuje društveni stav i mjesto osoba sa invaliditetom u društvu, utvrđujući na taj način obrazac po kome društvo i sistem zaštite regulira pitanje invalidnosti. 


\section{Medicinski model}

Medicinski model se javlja početkom tridesetih godina 20. stoljeća, iako njegovi korijeni sežu i mnogo ranije. Od samog početka predstavlja dominantan model jer je podržan napretkom znanosti i medicine. Ovaj model zagovara stav da je bolest isključivo problem individue, a izazvana je povredom ili drugim vidom pogoršanja zdravlja pojedinca. Ovakvim tumačenjem „medicinski model je usmjeren na specifično oštećenje osobe i na taj način problematizira osobu, gledajući na nju kao objekt kliničke intervencije " (Quinn \& Degener, 2002). Zapravo, medicinski model nastoji da objasni, dijagnosticira, tretira i liječi invaliditet kao patologiju čime daje naglasak na organsko-funkcionalne uzroke koji se klinički orijentiše na liječenje i rehabilitaciju. Cilj kliničke intervencije i medicinske rehabilitacije je prilagođavanje osobe okolini i usredotočenost na njena ograničenja u pogledu obavljanja određenih aktivnosti. $\mathrm{Na}$ primjer, od djeteta sa oštećenim sluhom se očekuje da nauči govoriti, kako bi se uklopilo u zajednicu, ali se od odgajatelja, nastavnika i ostale djece ne očekuje da nauče znakovni govor kako bi lakše komunicirali sa njim.

Medicinski model zanemaruje činjenicu da osoba, unatoč oštećenju, i dalje ima određeni postotak sposobnosti da izvršava neke od aktivnosti. Subjektivni doživljaji pacijenta nije u fokusu rada ljekara, a odnos pacijenta i liječnika je hijerarhijski određen - distanciran je. Medicinski model donosi značajne promjene u društvenim odnosima spram osoba sa invaliditetom čije psiho-fizičko stanje zahtijeva stručnu pomoći ili asistenciju od druge osobe. Pod uticajem medicinskog modela otvara se veći broj specijalnih škola, ustanova, radionica, fondova, specijalnih metoda rada i slično. Osnovni princip rada sastojao se u pružanju zaštite, njege i smanjivanje rizičnih faktora u okruženju na najmanju moguću mjeru. Zadatak društva u okviru medicinskog modela bio je organizirati određene specijalne službe i postupke kojima bi se ublažile posljedice oštećenja. Naširoko prihvaćen medicinski model doveo je do toga da su odluke u vezi sa obrazovanjem i zaštitom djece zavisile od odluka komisije za kategorizaciju. Ukoliko bi komisija za kategorizaciju utvrdila da se radi o težem obliku onesposobljenja, u većini slučajeva došlo bi do izdvajanja djeteta iz njegove prirodne okoline i segregacija u specijalne ustanove. 
Sredinom šezdesetih godina politika različitosti, posebnih propisa, socijalnih mjera i oblika pomoći osobama sa invaliditetom doživljava prve oštre kritike. „Zagovornici promjene medicinskog modela bili su pristalice zaštite mentalnog zdravlja, a udružili su se u antipsihijatrijski pokret. Medicinski pristup mijenjaju u, tzv. socijalni pristup ili model“ (Flaker, 1998). Taj pomak omogućio je novi i sasvim drugačiji uvid u potrebe korisnika, ne samo u oblasti medicine, nego i u drugim područjima, poput socijalnog rada. Sada se uzroci invaliditeta dovode u vezu sa okrutnim okuženjem u kojem osoba živi, radi i obrazuje se.

Umjesto termina invaliditet nerijetko se koristi i termin hendikepiranost (handicap- handicapped) koji je kovanica od engleskih riječi hand= ruka i cap = kapa, a asocira na historijski težak socijalni položaj i siromaštvo osoba sa invaliditetom. Hendikep znači gubitak, nedostatak ili ograničenje mogućnosti ili šanse za ravnopravno sudjelovanje u životu društvene zajednice. Njime se pojašnjava nesuglasje ili suprotnost pa i sukob između osobe i njene okoline zbog čega je nužno dijagnosticirati i kontrolirati, ne samo činitelje na strani osobe, nego i na strani njene okoline koja podupire ili koči jednake mogućnosti za sve. Također, susreću se i različiti termini, poput posebne potrebe, koji treba izbjegavati jer je izrazito stigmatizirajući. Neki autori sugeriraju da se umjesto njega koristi termin dodatne potrebe, koji je isto tako vrlo ograničavajući termin.

\section{Model deficita}

Prvi svjetski rat (1914-1918) pridonio je stvaranju povoljnog položaja osoba sa invaliditetom, naročito onih nastradalih u ratu. Dolazi do otvaranja novih ustanova za slijepe, gluhonijeme i tjelesne invalide. Te institucije su egzistirale i u prošlom stoljeću. „Nakon ekspanzije tih ustanova tokom dvadesetih godina, nacionalsocijalisti su (1935) ustanovili specijalne razrede i pomoćne specijalne škole $s$ postupkom sterilizacijskog nadzora" (Gudjons, 1993:253).

Postupak sterilizacijskog nadzora pronašao je plodno tlo u ranom nacističkom pokretu kada nacionalsocijalistička stranka 1930. donosi zakon koji omogućuje prisilno steriliziranje shizofrenih osoba, osoba sa epilepsijom, mentalno oboljelih, osoba sa oštećenim sluhom i vidom. 
Adolf Hitler je na temelju ovog zakona razvio program eutanazije (1939) gdje su zagovornici negativne eugenike u Njemačkoj od 1932. do 1945. prisilno sterilizirali oko 360000 osoba $s$ invaliditetom, a na desetine hiljada ubili. Hitlerova netolerancija prepoznata je u njegovom djelu "Mein Kampf", u kojem osobe sa invaliditetom naziva defektnim, i koje treba spriječiti da šire jednako defektno potomstvo. Pod pojmom spriječiti podrazumijeva likvidaciju. On u svom djelu navodi: „Ako bude neophodno, neizlječivo bolesni će bez milosti biti odvojeni, kao barbarska mjera za nesretnika koji je time pogođen, ali blaženstvo za njegove bližnje i potomstvo" (prama, From, 1980:226). Tokom Drugog svjetskog rata (1940-1945) sudbina mentalno nerazvijenih i duševno bolesnih osoba i dalje je bila predmet diskriminacije. Fašizam, zagovarajući čuvanje čiste rase, ponovno oživljava praksu likvidacije ovih osoba. Komandant logora Sobibor i Treblinka, kojeg je Himler 1940. godine postavio na čelo Instituta za eutanaziju, imao je za cilj da mentalno oboljele i invalidne osobe pošalje na ubijanje. Ideja o međunarodnoj regulaciji prava i sloboda svih ljudi, pa i osoba sa invaliditetom, rađa se polovinom 20. stoljeća, a povod su svakako stradanja u Drugom svjetskom ratu, što je rezultiralo osnivanjem Ujedinjenih naroda i proglašenjem Opće deklaracije o ljudskim pravima 1948. godine. Model deficita obuhvata period šezdesetih godina 20. stoljeća. U samom nazivu modela, koji je opisan kao deficit, naglašen je način na koji su osobe sa poteškoćama u razvoju bile tretirane. Model deficita nesposobnost preusmjerava na dijagnosticiranje „onoga što osoba ne može“, a patologiju tretira kao „ono u čemu ima teškoće“. Shodno dijagnosticiranom deficitu, politika zdravstva usmjerava osobu ka određenim specijalnim službama i postupcima kojima se nastoje ublažiti posljedice oštećenja ili bolesti. Ako to nije moguće, osoba se izdvaja iz svoje prirodne okoline i upućuje u institucije u kojima se nastoji potaknuti društveno prilagođavanje pojedinca i postići pozitivne promjene u njegovom ponašanju. $\mathrm{Na}$ ovaj način podržava se ideja da osobe $s$ određenim nedostatkom treba da budu promijenjene, poboljšane i učinjene normalnijim. „Tradicionalna defektološka dijagnostika, polazeći od etiološke dijagnostike, shvata defekt kao osnovu za odabir defektne djece i njihovo uključivanje u specijalne škole. Ovaj vid selekcije je kod nas ozakonio Pravilnik o evidenciji i kategorizaciji (1960), kojim se dobiva 
jedinstvena nacionalna podjela osoba $s$ hendikepom. „Time se otvara proces ekspanzije osnivanja samostalnih ustanova za školovanje defektologa i izgradnje defektološke doktrine" (Biondić, 1993:74). Model deficita je u odnosu na medicinski model ponudio nešto humaniji pristup, dopuštajući osobama s poteškoćama u razvoju da se odgajaju i obrazuju u specijalnim školama. Shodno tome, dolazi do diferencijacije specijalnih škola. Osnivaju se odjeljenja ili škole za učenike sa mentalnim poteškoćama u razvoju, škole za slijepe i gluhe, itd. Sagledavajući politiku i praksu tretiranja funkcionalnih nedostataka koje defektologija i njena dijagnostika zagovaraju, krajem šezdesetih godina dolazi do jakih kritika modela deficita od strane biheviorista, psihoanalitičara i protivnika teorije etiketiranja.

Kritika se odnosila na stigmatizaciju osoba koje su zbog svog onesposobljenja izdvojene iz prirodnog okruženja, na činjenicu da princip rada nije uvažavao razvojne mogućnosti i sposobnosti pojedinca. Nakon kritike dijagnostike, razvila su se dva suprotstavljena dijagnostička modela:

Devijacijski model ili tip dijagnoze koji se javlja šezdesetih godina. Ciljevi dijagnosticiranja u ovoj koncepciji su usmjereni ka tome da se odredi kategorija ili klasa teškoća socijalne integracije čije su karakteristike izrazito ispod prosječnog ponašanja s obzirom na dob. Osim klasifikacije dijagnoze, ovaj model uvodi opis problema i ustanovljava etiologiju koja služi prognozi i proceduralnom tretmanu takvog stanja.

Habilitacijski model koji se javlja pod sintagmom pedagoška dijagnostika, čije je područje poteškoća socijalne integracije, široko je usmjereno i uvažava različite aspekte individue, poput: ponašanje korisnika, njegovo doživljavanje, evaluiranje različitih socijalnih iskustava itd. Pedagoška dijagnostika se ne zadržava isključivo na uzročnim, već uvažava i cirkularne ovisnosti i njihove međusobne odnose (Fisseni, 1990). Ona prvenstveno polazi od individualnog promaknuća pojedinačnog učenika čiji odgojni proces usmjerava ka njemu. Naime, ovaj model je ujedno i dijagnostika i proces podučavanja koji daje praktično-odgojne upute za promjenu postojeće situacije. 
Oba modela, medicinski i model deficita, sa aspekta rehabilitacije, podrazumijevaju višekratne, simultane intervencije usmjerene prema uzroku i sekundarnim posljedicama ozljede ili bolesti. U deficitnom modelu i dalje je prisutna segregacija koja odvaja učenike s razvojnim poteškoćama u zasebne institucije i onemogućuje im aktivno uključivanje u rad i ravnopravni status sa ostalim osobama. Ali, isto tako, zahvaljujući habilitacijskom modelu, dolazi se do novih spoznaja koje odbacuju tezu da osobe sa umjerenom mentalnom retardacijom nisu odgojive i da im nije mjesto u obrazovnom sistemu.

Shodno politici koja je vladala sedamdesetih, diferencijalne specijalne škole postaju dio općeobrazovnog školstva, a rade ovisno o razlikama koje su specifične za djecu sa smetnjama.

Prema Gudions (1993:253) razlikuju se sljedeće specijalne škole:

- škole za djecu sa smetnjama u učenju su grane specijalnih škola u kojima se učenicima pružaju temeljna iskustva koja društveno okruženje ne može dostatno da im pruži;

- škole za djecu sa psihičkim smetnjama u kojima se nudi životno, praktično i motoričko osposobljavanje;

- Škole za poremećaje u ponašanju, tzv. škole za neodgojivu djecu.

Utemeljenje isključivanja iz obrazovnog sistema osoba sa teškoćama u razvoju je u uskoj vezi sa klasifikacijom Kvebeškog odbora za međunarodnu klasifikaciju oštećenja, invalidnosti i hendikepa (ICIDH). „Svjetska zdravstvena organizacija (SZO) invaliditet definira kao bilo kakvo ograničenje ili nedostatak, koji proizlazi iz oštećenja zdravlja, sposobnosti za izvršavanje neke fizičke aktivnosti ili psihičke funkcije na način ili u opsegu koji se smatra normalnim za ljudsko biće ovisno o njegovoj dobi“ (SZO, 1980).

Međunarodna klasifikacija oštećenja, invalidnosti i hendikepa (ICIDH) je bazirana na medicinskom modelu koji posmatra onesposobljenje kao problem osobe, direktno uzrokovan oboljenjem, traumom ili nekim drugim zdravstvenim stanjem koje zahtijeva medicinsku brigu pruženu u formi individualnog tretmana od strane profesionalaca. Tretiranje 
onesposobljenja je usmjereno ka izlječenju ili prilagođavanju pojedinca i promjeni ponašanja. Medicinska briga se posmatra kao glavno pitanje, a na političkom nivou, osnovni odgovor je modificiranje ili reformiranje politike zdravstva (ICF, 2001:20). Reformiranje politike zdravstva u osamdesetim godinama 20. stoljeća je uticalo i na reformu osnovne škole. $\mathrm{Na}$ snazi je kritika specijalnih škola, jer su postupci dokazivanja da je neko za specijalnu školu, neprimjereni i nedovoljno dokazivi. U svim kulturama postoje određena minimalna očekivanja u pogledu temeljnih funkcija $u$ raznim područjima. Također, kritika upućuje i na neznatne šanse za zaposlenje nakon završene specijalne škole. Sve ovo je utjecalo na reformu obrazovnog sistema u kojoj se djeca sa smetnjama u razvoju nastoje integrirati u redovnu nastavu. Jedan od poznatih modela je kaskadni model čija je autorica Evelyn Deno (1970).

Kaskadni model je baziran na odgojno-obrazovnom kontiniumu koji teži ka ostvarenju što manje restriktivne sredine u nastojanju da svakom djetetu osigura takvo okruženje od kojeg će imati najviše koristi. "Iako predstavlja zamišljeni oblik modela, ovaj sistem rješava obrazovanje osoba sa posebnim potrebama u rasponu od specijalnih škola do povremene edukacije u redovnim razredima" (Hegarty, Pocklington, 1984). Obrazovanje djece sa posebnim potrebama je u ovom sistemu organizirano kroz sedam sljedećih nivoa:

N1 - uključivanje djece sa posebnim potrebama u redovan odgojnoobrazovni proces, i to djece koja mogu napredovati bez medicinskih ili drugih pomoćnih terapija;

N2 - pohađanje redovne škole uz dodatnu stručnu pomoć;

N3 - djelomičan boravak u specijalnom odjeljenju, a djelomičan u redovnom odjeljenju;

N4 - svakodnevni i potpuni boravak u specijalnom odjeljenju;

N5 - smještaj djeteta u specijalne ustanove;

N6 - obrazovanje kod kuće za djecu koja iz zdravstvenih razloga ne mogu pohađati školu; 
N7 - hospitalizirano obrazovanje za djecu koja nastavu prate u bolničkim uvjetima.

Dunnov model (1973) je modificirani kaskadini model, poznat kao model introvertirane piramide, a razrađen je na principu izbora programa za opise tipova djece sa posebnim potrebama. On dijeli djecu na četiri kategorije i utvrđuje jedanaest organizacijskih planova koji se prožimaju od potpune integracije do potpune segregacije (Dunn,1973). Ovaj model razlikuje četiri oblika odgojno-obrazovnog rada:

- uključivanje u redovni odgojno-obrazovni program uz dopunski didaktički materijal i konsultativnu stručnu službu;

- djelomično uključivanje u redovni odgojno-obrazovni program uz direktnu pomoć specijaliziranog stručnjaka;

- uključivanje u redovni odgojno-obrazovni program uz pohađanje specijalnog programa;

- $\quad$ smještaj u specijalne škole internatskog tipa.

- Socijalni model

Krajem 80-ih politika i ekonomija snažno utiču na promjenu položaja i mjesta pojedinca u društvenoj zajednici. Globalizacija svijeta donosi promjene u međuljudskim odnosima i veću informiranost o ljudskim pravima i slobodama. Početkom 90-ih godina 20. stoljeća dolazi do pojave socijalnog modela koji stavlja naglasak na promjenu okoline, naročito škole, sa aspekta adekvatnog obrazovanja. Škola treba da se prilagodi pojedincu, a ne pojedinac njoj. Krajem 90-ih godina 20. stoljeća nastavlja se ideja integracije, koja odbacuje koncept invaliditeta kao posebnog stanja individue i pravi razliku između osoba koje imaju različite mogućnosti. Zakon omogućuje školovanje učenika s blažim poteškoćama u razvoju u redovnim školama u cilju optimalnog razvoja i minimizacije efekata etiketiranja i stigmatiziranja ove populacije. Djeca sa težim poteškoćama, u zavisnosti od onesposobljenja, i dalje se upućuju u posebne obrazovane institucije specijalizirane za takvu pomoć. Naime, takav vid rada se nameće logičnim, jer integracija ima i svoje granice. Odgojni rad na području specijalnog odgoja traži posebne programe, metode, organizaciju, opremu 
i posebno pripremljene stručnjake. Dijeljenje zajedničkog prostora u redovnim školama i neke aktivnosti organizirane $u$ ograničenom vremenskom periodu su pod strogom kontrolom stručnih osoba i ne omogućuju istinsko uključivanje i uvažavanje dječijih potreba. Integracija djece sa smetnjama, u postojeći sistem obrazovanja - redovne škole, bez prilagođavanja njihovim posebnim obrazovnim potrebama, zahtijeva od djeteta promjenu i prilagodbu školi, sa naglaskom na školskom postignuću. Nastavni plan i program je u centru nastavnog procesa, a ne učenik sa svojim specifičnim mogućnostima, znanjima, interesovanjima i iskustvom. Ako učenik ne uspije da se prilagodi u redovnom odjeljenju, slijedi mu isključenje. U takvom procesu učenik je manje stigmatiziran, ali i dalje nije dobio adekvatnu potporu za učenje i samostalni rad.

U okviru socijalnog modela javljaju se različiti sistemi integracije djece sa onesposobljenjem u odgojno-obrazovnom procesu:

- sistem introvertirane piramide;

- $\quad$ mainstreaming sistem;

- model individualizacije

- parcijalna integracija po sistemu posebnih soba;

- model parcijalne integracije

- $\quad$ sistem patronažne integracije;

- kaskadni sistem;

Mainstreaming sistem je jedan od vidova integracije koji se primjenjuje $u$ SAD. On naglašava potrebu uključivanja djece sa posebnim potrebama $u$ sve glavne tokove života. Reynolds (1975) ističe da su za uspješnu socijalizaciju odlučujuće rane godine života, te je potrebno ukinuti izdvajanje djece sa teškoćama u razvoju u specijalne vrtiće i škole. On smatra da ih treba odmah uključiti u redovne škole, kako bi od najranijih dana sticali socijalno iskustvo u svijetu većine. Naime, on zagovara boravak djece u specijalnim uvjetima samo u slučaju krajnje potrebe. Kada se ostvare minimalne pretpostavke za djetetovu integraciju, automatski se realizira prelazak u redovnu školu uz određen broj sati povremenog 
specijalnog obrazovanja (eng. Par time special education). Naredni nivo podrazumijeva potpuno uključivanje djece u redovne škole u kojima se nastava odvija po posebnom programu.

Model individualizacije kreirao je Muth (1975), a bazira se na individualnom radu sa djecom koja imaju poteškoće u razvoju. On ne isključuje mogućnost rada i druge djece po ovoj metodi ukoliko imaju senzorna ili tjelesna oštećenja. Metodologija rada je kreirana tako što su djeca uključena u posebne dopunske edukativne tretmane uz obezbjeđenje stručnih lica. Individualizirani pristup podrazumijeva da, prilikom pravljenja programa podrške, vodimo računa o uvažavanju nivoa funkcioniranja i potreba konkretnog djeteta, o njegovim interesovanjima i karakteristikama socio-ekonomskog okruženja u kojem dijete živi.

Parcijalna integracija po sistemu posebnih soba se već duže vremena koristi $\mathrm{u}$ američkom obrazovnom sistemu. Naime, kreirana je tako da djeca sa poteškoćama u učenju budu smještena u redovnu školu u kojoj egzistira jedna prostorija, tzv. posebna soba. U određenim vremenskim intervalima djeca borave u ovoj prostoriji i primaju stručnu pomoć.

Model parcijalne integracije je kreiran na principu posebnog odjeljenja sačinjenog od tročlane skupine djece sa višestrukim teškoćama u razvoju. Nastavni plan i program se realizira pod posebnim uvjetima i prilagođen je svakom pojedinom djetetu u zavisnosti od stepena oštećenja. Cjelokupna podrška i edukacija je vođena od strane stručne službe koja obavezno uključuje defektologa.

Sistem patronažne integracije je jedan od vidova odgojno-obrazovne rehabilitacije koji se primjenjuje u porodici ili $\mathrm{u}$ hospitaliziranim institucijama. Obuhvata rad hronično oboljele djece ili djece sa teškim oblicima tjelesnog invaliditeta, zbog kojih nisu u mogućnosti pohađati redovnu školu. U zemljama Zapadne Evrope ovaj vid odgojnoobrazovanog rada financira država.

Kaskadni sistem je u većini zemalja Zapadne Evrope sa postojećom legislativom omogućio objektivne pretpostavke za integraciju djece sa posebnim potrebama u redovne i specijalne škole. Shodno kaskadnom 
modelu, Uhlendorff (2012) razlikuje pet područja odgoja i obrazovanja osoba sa poteškoćama u razvoju u sistemu socijalne integracije:

(1) rano područje: Tu se ubrajaju ponude za djecu do 3 . godine života, kao npr. centar za rano poticanje, odnosno socijalno-pedijatrijski centar koji skrbi medicinski, terapeutski i pedagoški za djecu s invaliditetom. Bach (1999:127) ističe da ovi centri imaju za cilj ranu dijagnostiku, prevenciju, savjetovanje roditelja, upućivanje roditelja na metode ranog odgoja, emocionalnu stabilnost roditelja, posredovanje rane liječničke dijagnoze i rane terapije.

(2) elementarno područje: Za djecu od treće godine života do polaska u školu, tzv. specijalni vrtić ili vrtić za poticanje u kome je središnje područje rada pomoć djeci sa teškoćama u razvoju. Tu se primaju djeca koja ne dovoljno poticaja u redovnom vrtiću. U sklopu rasprave oko načela normalizacije može se primijetiti da se sve više djece s teškoćama u razvoju uključuje u integracijske dječje vrtiće zajedno s ostalom djecom, te se ondje potiče njihov razvoj. Bach (ibid.) navodi i nužnost specijalnih vrtića koji su u tijesnom kontaktu sa redovnim dječijim vrtićima koji imaju specijalnu opremu i kadar.

(3) školsko područje: Za djecu sa teškoćama u razvoju i mlade u školskoj dobi postoje specijalne škole usmjerene na posebne potrebe, kao npr. škole za djecu sa teškoćama u učenju, za gluhu djecu i djecu oštećenoga sluha. Mnoge škole moguće je završiti na svim nivoima (završetak osmogodišnje škole, matura srednje škole i opća matura). Bach (ibid.) smatra da specijalne škole imaju opravdanje samo ukoliko su obilježene posebnom ometenosti kao što navodi i Uhlendorff (2012). On smatra da specijalne škole treba povezati sa redovnim školama, kako bi izvan nastave specifične za ometene, mogle pospješiti mnoge kontakte između ometene $\mathrm{i}$ neometene djece (npr. zajedničko igralište, dvorište, sportska dvorana, partnerski projekti itd.)

(4) područje strukovnog obrazovanja: Nakon završetka škole mladima sa teškoćama u razvoju stoje na raspolaganju brojne mjere nalaženja posla i pripreme za zanimanja, kao npr. pripremna godina za učenje zanimanja. Bach (ibid.) je mišljenja da bi djeca sa posebnim potrebama trebala, u 
okviru mogućnosti, pohađati redovne škole strukovnog obrazovanja. Ta zanimanja ne bi smjela biti označena kao priučena ili invalidska, čime bi se diskriminirala. Samo u slučajevima sljepoće ili gluhoće djeca trebaju nastaviti pohađati neophodne specijalne škole za dalju izobrazbu.

(5) područje obrazovanja odraslih: Ovim područjem dominiraju, tzv. radionice za osobe s teškoćama u razvoju. One trebaju omogućiti odraslim osobama uključivanje u svijet rada. Bach (ibid.), navodi da osobe sa invaliditetom u odrasloj dobi treba da prođu nužni tečaj za profesionalnu prekvalifikaciju kao i poticajne radionice. Mišljenja je,također, da bi trebalo ukinuti razne udruge ili klubove čije je djelovanje jednostrano, uskogrudno fiksirano za oštećenje ljudi. Osobama s invaliditetom su potrebni poticaji i podrška u okruženju neometenih osoba.

Bez obzira o kojem vidu modela integracije je riječ, Tolon i Belsky (1985) ističu da je socijalna integracija ostvarena tek onda kada je uspostavljen najveći stepen komunikacije, spontanosti i harmoničnog rada u odgojnoobrazovnom procesu. Da li će to biti postignuto, u mnogome zavisi od prethodnih komponenti: prevencije, dijagnostike i rehabilitacije. „Naročito je važna valjana dijagnostika od strane stručnih lica koja je preduvjet za proces planiranja i programiranja primjenjivih rehabilitacijskih postupaka čime se utvrđuje položaj djeteta spram druge djece“ (Stančić, 1985). Naime, ranim tretmanom mogu biti korigovani mnogi nedostaci još prije polaska djeteta u školu. „Time je omogućen sigurniji start za savladavanje obrazovnog programa“ (Teodorović, 1987).

\section{Pojmovno određenje sintagme posebne potrebe}

Termin posebne potrebe je preuzet iz engleskog jezika i ne odgovara $u$ potpunosti potrebama našeg govornog područja, jer nije dovoljno jasan i precizan. Npr. dijete sa posebnim potrebama i dijete sa smetnjama u razvoju nisu sinonimi, jer su djeca sa smetnjama u razvoju samo jedna grupa djece koja pripadaju kategoriji djece sa posebnim potrebama. Riječ dječija potreba nalazimo još u stavovima L.S. Vigotskog (1924), kada kaže „Specijalna obuka treba izgubiti svoj specijalni karakter kako bi postala dio općeg odgojnog djelovanja koje se mora usmjeriti prema dječijim potrebama" (prema, Biondić, 1993:24). Osim toga, ovaj termin nije 
odgovarajući ni sa aspekta psihološkog shvatanja potreba, jer svi ljudi imaju u osnovi iste potrebe, ali načini njihovog zadovoljavanja mogu biti otežani i/ili različiti. Individualne razlike su prirodne, a kako razvoj ne teče pravolinijski, svako dijete u nekom periodu svog razvoja može imati neku poteškoću, pa će mu biti potrebna individualna pomoć i podrška.

Stručnjaci različitih disciplina koriste i različite sintagme: psiholog posmatra osobu s invaliditetom kao ometenost osobnosti; liječnik kao medicinsko-patološki problem; pravnik se fokusira na formalno-pravne aspekte statusa te osobe; sociolog posmatra položaj u društvenoj zajednici; dok socijalni radnik posmatra njegov položaj u porodici i društvu. U obrazovnom sektoru prihvatljivo je koristiti termin posebne obrazovne potrebe jer se tako opisuju sva ono djeca koja imaju teškoće u učenju, a koje mogu biti posljedica ometenosti ili nekih drugih nepovoljnih okolnosti, pa im je potrebna posebna podrška i pomoć tokom obrazovanja. (Shema br.1) Termin posebne potrebe najčešće se koristi u kontekstu razumijevanja obrazovnih, religijskih, jezičkih, socijalnih, kulturoloških i drugih potreba, dok se sintagma teškoće u razvoju koristi isključivo u opisu stanja malodobne osobe. (ICIDH) International Clasification of Impairments (1997) to definira na sljedeći način: „Dijete sa smetnjama u razvoju je dijete koje ima teškoće u razvoju i nije u mogućnosti da postigne ili održi zadovoljavajući nivo zdravlja i razvoja ili čije zdravlje i razvoj mogu značajno da se pogoršaju bez dodatne podrške ili posebnih usluga u oblasti zdravstvene zaštite, rehabilitacije, obrazovanja, socijalne zaštite ili drugih oblika podrške“ (World Health Organization (1997). Pojam osoba s invaliditetom (OSI) se može koristiti kao univerzalni pojam jer je definiran u Konvenciji ujedinjenih nacija-prava osoba s invaliditetom (2008), kao jednom od najvažnijih međunarodnih instrumenata za zaštitu ove populacije. Termin (OSI) osigurava interdisciplinarno sporazumijevanje i zajedničko djelovanje bez čega je nezamisliva pomoć ovim osobama. U nazivu OSI fokus je na ključnoj riječi invaliditet (lat. in-validus: nevrijedan, ne-sposoban) i najčešće podrazumijeva onoga ko je zbog tjelesnog, intelektualnog ili duševnog oštećenja djelomično ili potpuno izgubio određenu sposobnost. Prema Klaiću (1958:553) validan (lat.) = zdrav, jak, čvrst, moćan, koji vrijedi, a invalidan (lat.) = nejak, slab, 
nemoćan, čovjek koji je u ratu ili vršenju svog zanimanja stradao i postao potpuno ili djelomično nesposoban za rad.

Sintagma OSI se odnosi na različite vrste i stepene oštećenja, teškoća ili smetnji u području fizičkog, psihičkog, intelektualnog, duševnog, psihofizičkog i socijalnog razvoja. Pripada kategoriji, tzv. opće za razliku od posebne i pojedinačne terminologije invaliditeta (odnosi se na specifično oštećenje koje rezultira invaliditetom, npr. intelektualne teškoće). Radi procjene potreba, planiranja i ostvarivanja prava OSI, u međunarodnoj klasifikaciji SZO-a, zdravstvena stanja osoba su različito definirana u zavisnosti o tome da li se radi o bolesti, oštećenju ili ozljedi. Ova podjela je 1980. godine primarno klasificirana u priručniku za međunarodnu klasifikaciju bolesti (MKB-10), tzv. 10. revizija Međunarodne klasifikacije bolesti i srodnih zdravstvenih problema (kratica: MKB-10) (engl. International Statistical Classification of Diseases and Related Health Problems ICD-10). U njoj su definirani kodovi za bolesti, simptome, abnormalnosti i sl, klasificirani od Svjetske zdravstvene organizacije (engl. WHO). Različite definicije za pojam invalidnosti ponekad rezultiraju manjim ili većim praktičnim problemima. Takav slučaj je i sa Bosnom i Hercegovinom u kojoj ne postoji jedinstvena definicija osoba $s$ invaliditetom, jer su njihova prava regulirana u okviru entiteta. Zakonom o dječijoj zaštiti RS uređuje se niz prava za djecu sa invaliditetom, dok je potreba posebne zaštite za djecu s teškoćama u razvoju u F BiH prepoznata u Zakonu o osnovama socijalne zaštite, civilnih žrtava rata i porodica sa djecom.

U Bosni i Hercegovini ne postoji jedinstvena definicija osoba sa invaliditetom. U definiranju invaliditeta koriste se različiti pojmovi u različitim oblastima (socijalne, zdravstvene zaštite, penzionog osiguranja, zapošljavanja). U skladu sa zakonima $\mathrm{F} \mathrm{BiH} \mathrm{i} \mathrm{RS} \mathrm{o} \mathrm{profesionalnoj}$ rehabilitaciji, osposobljavanju i zapošljavanju, lica sa invaliditetom u F $\mathrm{BiH}$ su osobe kod kojih postoji tjelesno, čulno ili mentalno oštećenje koje za posljedicu ima trajnu ili privremenu, a najmanje 12 mjeseci smanjenu mogućnost rada i zadovoljavanja ličnih potreba u svakodnevnom životu

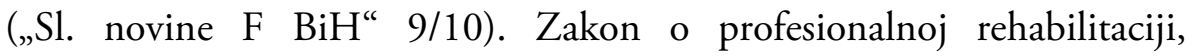
osposobljavanju i zapošljavanju invalida Republike Srpske daje sličnu 
definiciju, s tim da se umjesto termina lice sa invaliditetom, koristi termin invalid ("Službeni Glasnik Republike Srpske" broj 98/04). Svjetska zdravstvena organizacija prepoznaje potrebe integracije medicinskog i socijalnog modela kako bi sačuvala koherentnost različitih perspektiva biološkog, individualnog i društvenog funkcioniranja zdravlja. U 2001. godini urađena je revizija Međunarodne klasifikacije oštećenja, onesposobljenja i hendikepa u Međunarodnu klasifikaciju funkcioniranja, onesposobljenja i zdravlja, poznatu kao MKF (ICF). Ova klasifikacija invalidnost definira kao: "ishod ili rezultat kompleksnog odnosa između zdravstvenog stanja pojedinca i ličnih faktora, i vanjskih faktora koji predstavljaju uslove u kojima pojedinac živi” (ICF-International Classification of Functioning, Disability and Health). 191 država članice SZO-a potvrdilo je MKF, kao međunarodni standard za opisivanje zdravlja i invaliditeta. Sveukupni cilj MKF klasifikacije je obezbjeđenje jedinstvenog i standardnog jezika i okvira za opisivanje zdravlja i zdravstvenih stanja. Budući da je MKF, prije svega, zdravstvena klasifikacija, ona se koristi i u različitim sektorima koji su direktno ili indirektno povezani sa zdravstvenim sistemom: socijalne i druge forme osiguranja, socijalna politika, radna sposobnost, inkluzivno obrazovanje, ekonomija, unapređenje zakonodavstva, kao i mijenjanje okruženja. MKF je jednoglasno prihvaćena od Ujedinjenih naroda kao Međunarodna klasifikacija korištena u različite svrhe:

- $\quad$ kao statistički instrument za prikupljanje i pohranjivanje podataka u populacijskim studijama i istraživanjima ili u informatičkim sistemu podataka;

- kao klinički instrument za procjenu potrebe u izboru odgovarajućeg tretmana kod specifičnih stanja, procjena profesionalne sposobnosti, za rehabilitaciju i evaluaciju ishoda;

- kao instrument u socijalnoj politici u planiranju socijalnog osiguranja, sistema naknada, te u kreiranju socijalne politike i njezinoj primjeni;

- kao instrument u obrazovanju u izradi nastavnog programa, podizanju svjesnosti o poduzimanju odgovarajućih socijalnih akcija; 
- kao istraživački instrument za mjerenje, između ostalog, i kvalitete života.

Donošenjem Konvencije Ujedinjenih naroda o pravima osoba $s$ invaliditetom ICF 2006. godine definicija iz 2001. godine je dopunjena osobe sa invaliditetom smatraju se one koje imaju dugotrajna tjelesna, mentalna, intelektualna ili osjetilna oštećenja. Takva oštećenja i smetnje, u međudjelovanju s različitim preprekama, mogu sprječavati njihovo puno i učinkovito sudjelovanje u društvu (United Nations, 2006). U preambuli, Konvencija UN-a jasno se zalaže za socijalni model pristupa invaliditetu u kome se insistira na usmjerenosti ka socijalno-aktivnom položaju:

- oštećenje - uključuje organska oštećenja i funkcionalne smetnje;

- aktivnost - definira mjere osobnih ostvarenja;

- sudjelovanje - opisuje sudjelovanje pojedinca u životu društva.

Prema ovoj definiciji oštećenje ne treba negirati, treba ga prihvatiti da zbog toga osoba nije manje vrijedna, nego joj društvo treba pomoći u zadovoljenju njenih potreba i prava koja proističu iz Konvencije. „Iz navedene definicije može se uočiti da integracija OSI, nije adaptacija ili pasivno prilagođavanje sredini ili uklapanje u nju, kako se to nerijetko smatra i u praksi dešava, nego ona podrazumijeva aktivno uključivanje $u$ socijalnu sredinu i obogaćivanje te sredine originalnim doprinosom integrirane osobe" (Zovko, 1999).

\section{Uloga specijalne pedagogije u odgoju i obrazovanju djece}

Krajem XIX i početkom XX stoljeća dolazi do formiranja specijalne pedagogije kao znanstveno-pedagogijske discipline u sistemu pedagoških znanosti. Specijalna pedagogija bavi se problemom odgoja, obrazovanja i profesionalnog osposobljavanja djece i mladih sa teškoćama u razvoju. Savremena diferencijalna pedagogija, u okviru svog djelovanja, obuhvata i specijalnu pedagogiju koja svojim specifičnim zadacima osigurava odgoj i obrazovanje razvojno ometene djece i mladih prema njihovim mogućnostima. Zbog specifičnosti zadataka, specijalna pedagogija se transdisciplinarno oslanja na medicinske discipline: psiho-patologija, 
psihijatrija, neurologija, fonijatrija itd.. Budući da se radi o različitim vidovima ometenosti u razvoju, specijalna pedagogija je svoja ispitivanja i odgojno-obrazovni rad usmjerila $u$ različitim pravcima $u$ zavisnosti od vrste onesposobljenja. Tako su nastala njena uža područja ili grane:

- oligofrenopedagogija (odgoj osoba sa mentalnim poteškoćama);

- tiflopedagogija (odgoj slijepih i slabovidnih osoba);

- $\quad$ surdopedagogija (odgoj gluhih i nagluhih osoba);

- logopedska pedagogija (odgoj osoba s govornim nedostacima);

- medicinska pedagogija (odgoj hronično bolesnih i tjelesno invalidnih osoba);

- $\quad$ sociopatska pedagogija (odgoj i saniranje socipatskih stanja);

- socijalna pedagogija (odgajanje i preodgajanje, obrazovanje, obučavanje i profesionalno osposobljavanje odgojno zanemarene djece);

- forenzična pedagogija (odgoj djece s psihopatskim i neuropatskim smetnjama, odgoj maloljetnih prijestupnika);

- Sa stanovišta odgoja i obrazovanja, specijalna pedagogija koristi i druge nazive: pedagogija liječenja, zdravstvena pedagogija, korektivna pedagogija, integrativna pedagogija, odgoj djece sa posebnim potrebama, inkluzija itd. U predmetu proučavanja specijalnog odgoja, integrirane su sljedeće komponente:

- simptomatologija i sanacija razvojnih smetnji;

- habilitacija u cilju razvijanja novih funkcija i sposobnosti koje mogu kompenzirati oštećenja ili sticanje novih sposobnosti koje ranije nisu bile dovoljno razvijene;

- rehabilitacija sa ciljem ublažavanja i uklanjanja psihičkih i tjelesnih nedostataka.

Sve tri komponente pomažu u preodgajanju ili ublažavanju stanja osobe sa poteškoćama u razvoju. „U okviru predmeta izučavanja specijalnog odgoja posebna se pažnja pridaje organizaciji odgojno-obrazovanog procesa i 
modelima poučavanja koji se realiziraju u zavisnosti od stepena oštećenja“ (Stevanović, 2003:146).

\section{Inkluzivni pokret u obrazovanju}

Paralelno sa pokretom za specijalno školstvo, koji je nastao kada i pokret za obrazovanje sve djece, javio se pokret zasnovan na uvjerenju da je za dijete najbolje školovanje sa svojim vršnjacima i pod istim uslovima. Doprinos Marije Montesori u Italiji, Karla Štajnera u Austriji i Eduarda Klapareda u Švajcarskoj jeste u tome što su dali osnove za osnivanje inkluzivnog pokreta u obrazovanju. Termin inkluzija je latinskog porijekla (lat. inclusio) i ima sljedeća značenja:

- zatvaranje, zatvor, zagrada;

- uključivanje, sadržavanje, obuhvaćanje, podrazumijevanje;

- primjesa, sastojak, sastojina, sastavina;

- zaokruženost, zaobljenost.

U engleskom jeziku (engl.inclusive) ova riječ znači: uključivši, uključivo; obuhvaćajući, sadržavajući, podrazumijevajući (Klaić, 1982:591). Engleski termin inkluzija postao je općeprihvaćeni termin u pisanoj i govornoj komunikaciji kada govorimo o osobama sa posebnim potrebama $\mathrm{u}$ obrazovnom sistemu. Eduard Klapareda je inkluzivni pokret nazvao „Škola po mjeri djeteta“, a pokret je poprimio planetarne razmjere. Prema podacima UNICEF-a iz 1991. god. oko 126 zemalja je primijenilo modele psiho-socijalne podrške za djecu sa teškoćama u razvoju, koja su uključena $\mathrm{u}$ redovne škole.

Na konferenciji u Salamanki 1994. godine stavljen je naglasak na to da je inkluzija ideja koja je u direktnoj vezi s poboljšanjem obrazovnog sistema kao cjeline:

"Inkluzija je proces rješavanja i reagiranja na raznovrsnost potreba svih učenika kroz sve veće učestvovanje u učenju, kulturama i zajednicama i sve manju isključenost u okviru obrazovanja. Inkluzija obuhvata promjene i izmjene sadržaja, pristupa, struktura i strategija, sa zajedničkom vizijom koja obuhvata svu djecu odgovarajuće starosne dobi i sa ubjeđenjem da je 
redovni obrazovni sistem odgovoran za obrazovanje sve djece" (UNESCO,1994). Preporuke iz Salamanka dokumenta se odnose na sljedeće:

- svako dijete ima pravo na obrazovanje;

- svako dijete ima jedinstvene karakteristike, interesovanja, sposobnosti i obrazovne potrebe;

- obrazovni sistemi trebalo bi da oblikuju obrazovne programe koji će podržavati različitost među djecom;

- učenici sa smetnjama u razvoju moraju imati pristup redovnim školama, uz prilagođeno obrazovanje;

- redovne škole s inkluzivnom orijentacijom najbolji su način za prevazilaženje diskriminativnih stavova i izgradnju inkluzivnog društva.

Za razliku od socijalne integracije koja parcijalno uključuje osobu u redovni odgojno-obrazovni sistem, inkluzija podrazumijeva njegovo potpuno izjednačavanje i uključivanje sa prosječnom populacijom. Na taj način se osobe sa teškoćama u razvoju ne posmatraju i ne vrednuju prema njihovim nesposobnostima, ograničenjima i teškoćama, nego prema brojnim sposobnostima, interesima, jakim stranama i potencijalima. Zahtjev za podudarnost odgojno-obrazovnog rada sa potencijalnim snagama djeteta upućuje na cjelovito upoznavanje njegovih sposobnosti i otkrivanje jakih djetetovih strana. „Ako promatramo sistemska rješenja i društvenu podršku kroz izmjene i dopune međunarodnih pravnih akata koji osiguravaju ravnopravni status osoba s posebnim potrebama kao i promjene u svijesti pojedinaca koje se dešavaju od 1990. god. pa na ovamo, zasigurno možemo reći da se inkluzija nameće kao nadređeni pojam integraciji“ (Mišić, 1995). „Za razliku od integracije koja osobu usmjerava na institucije, inkluzija ohrabruje svaku osobu s intelektualnim teškoćama da preuzme, uz pomoć roditelja, staratelja ili odgajatelja, potpunu odgovornost za svoje učenje i ponašanje“ (Whittaker, 2000). Oduvijek je bilo primjera izvanredne ljudske volje pomoću koje su pojedinci savladavali i najteže prepreke. Savladavanje ovih prepreka u velikoj mjeri 
zavisi od socijalne interakcije sa drugim osobama. Naime, ako dijete ne može samostalno da riješi složene zadatke, ono će biti sposobno da dođe do uspješnog rješenja u okviru interakcije sa odraslom osobom - osobom koja posjeduje kognitivnu strukturu neophodnu za rješavanje danog zadatka. Mel Ainscowsa Ainscow, Hopkins, Southwoth i Westa (1994) naglašavaju šest uslova za uspješan razvoj inkluzije:

Vođstvo koje ne podrazumijeva samo direktora nego i sve koji su uključeni u rad škole. Ainscow ističe važnost lidera za stvaranje jasnih vizija inkluzije. Suprotno autoritetu, stvaraju se i timovi čiji je rad baziran na znanju i iskustvu. U ovom preduvjetu pažnja je usmjerena na klimu koja utiče na rješavanje problema i dodjelu vodećih funkcija članovima osoblja;

Participacija je od velike važnosti za aktivno uključenje učenika i roditelja $\mathrm{u}$ proces inkluzije. Ona, pored uključivanja učenika i roditelja, podrazumijeva uključivanje nastavnika kroz planiranje nastavnih sadržaja i organizaciju nastavnih metoda u radu sa učenicima;

Koordinacija se odnosi na povećanje sposobnosti i aktivnosti nastavnika i drugih nositelja funkcija prema dogovorenim načelima i ciljevima. Nastavnici imaju dovoljno autonomije da donesu odluke koje se tiču individualnog rada učenika. Svjesni su postojanja uticaja neformalnih grupa na formalne strukture koje egzistiraju u odgojno-obrazovnom procesu;

Refleksija je važna za uspostavljanje sistematičnog prikupljanja, analizu i interpretaciju informacija u školi. Ona znači da je potrebno uključiti svo osoblje u informacioni menadžment;

Usavršavanje osoblja ima značajan uticaj na razmišljanje i praksu koja je povezana sa razvojem i unapređenjem rada škole. Ključne komponente usavršavanja osoblja su: opisi vještina i strategija, modeliranje ili demonstracija vještina, praksa u stimuliranim sredinama, strukturiran povratni odgovor feed-back i motivacija.

Kod uvođenja inkluzije u obrazovni sistem nužno je provesti niz sistemskih mjera koje će stvoriti zakonske pretpostavke za uključivanje djece sa teškoćama u razvoju u redovan školski sistem. Naime, inkluzivno 
obrazovanje treba da zadovolji sve potrebe učenika i da kontinuirano radi na poboljšanju učešća i eliminaciji isključenosti iz svih aspekata školovanja i to na način da se nijedan učenik ne osjeća drugačijim. Booth (2000) i Vayeyen (2001) navode preduvjete za uvođenje inkluzivnog obrazovanja:

- unapređenje kurikuluma kreiranjem fleksibilnih nastavnih planova i programa prilagođenih individualnim potrebama učenika;

- reguliranje pravnog sistema i sistema podrške;

- fizički uvjeti za prihvatanje onesposobljene djece uz opremljene prostorije i adekvatna nastavna sredstva;

- dobro razrađene različite nastavne metode kroz participiranje i dizajniranje programa učenja koji odgovaraju individualnim sposobnostima učenika;

- $\quad$ usklađeno brojno stanje u odjeljenjima u kojima su integrirana djeca sa posebnim potrebama;

- modificiranje nastavnih sadržaja koji su u korelaciji sa oblastima koje se proučavaju;

- tehničko-materijalna opremljenost (osiguranje transporta invalidnih lica, auditivni aparati za trening osoba sa oštećenjem sluha, Brailleovo pismo, stručna literature);

- promjena na nivou školskog menadžmenta kroz profesionalno vođenje i usmjeravanje;

- provođenje sistemskih mjera u partnerstvu sa roditeljima i lokalnom zajednicom u smislu pripreme za prihvatanje djece sa posebnim potrebama;

- priprema učenika za prihvatanje svojih vršnjaka;

- obuka nastavnog kadra putem seminara, zborovanja, savjetovanja, simpozija za rad u inkluzivnom odjeljenju;

- uključivanje stručnjaka specijalista za različite vidove onesposobljene djece. 
Imajući u vidu da se radi o učenicima sa teškoćama u učenju, znatno većih od svojih vršnjaka, potrebna je posebna odgojno-obrazovna i materijalna podrška. „Prihvatanje inkluzije otvara put za razvoj pozitivnih vrijednosti: gdje suradnju stavlja nasuprot suprotstavljanju, socijalnu interakciju umjesto izolacije, međuzavisnost i prijateljstvo umjesto osamljivanja“ (Šarenac, 2003).

Prosvjetni radnici u školama imaju veoma važnu ulogu u kontekstu sagledavanja školskog okruženja u kojem ova djeca uče. Naime, svako dijete $s$ teškoćama u razvoju ima različite sposobnosti za učenje, različite potrebe i interese. Zbog svih navedenih, kao i drugih razloga, odgojni proces treba individualizirati, uvažavati i staviti u kontekst različitih sposobnosti, interesa i potreba. $\mathrm{Na}$ taj način omogućit će se poštovanje $\mathrm{i}$ zadovoljavanje prava sve djece da pohađaju najbliže vrtiće zajedno sa svojim vršnjacima. Za svako dijete sa posebnim potrebama nužno je odrediti obrazovne potrebe i prema njima uraditi prilagođeni program. On treba da osigura optimalno korištenje njegovih potencijala i ponudi modele adekvatne podrške. Posebne odgojne potrebe u okviru specijalnog odgoja nisu samo determinirane djecom koja imaju umanjene sposobnosti, nego se specijalni odgoj kroz inkluzivni pristup nastoji afirmirati i u odnosu na djecu sa natprosječnim koeficijentom inteligencije.

\section{Od segregacije do inkluzije}

Pomak od medicinskog modela ka inkluzivnom napravio je značajne iskorake $u$ načinu razmišljanja i pružanju podrške osobama sa onesposobljenjem. On je naročito došao do izražaja nakon što je Generalno vijeće UN-a 2006. godine potpisalo Konvenciju o pravima osoba s invaliditetom. Shodno Konvenciji, jedna od značajnih promjena odnosi se na upotrebu termina koji su do tada imali zastarjeli ili uvredljivi izraz. U naredne tri tabele nastojat ćemo da vam slikovito predočimo razvojni put razumijevanja osoba s invaliditetom, od faze segregacije do faze inkluzije. U tabelarnom prikazu br.1 Gerison Lansdown (2009) navodi diskriminirajući i nediskriminirajući jezik prema osobama $s$ 
invaliditetom $\mathrm{i}$ razloge zbog kojih oni nisu prihvatljivi u pisanoj korespondenciji i govoru.

Tab.br.1 diskriminirajući i nediskriminirajući jezik

\begin{tabular}{|l|l|l|}
\hline $\begin{array}{l}\text { Zastarjeli ili } \\
\text { uvredljivi izrazi }\end{array}$ & $\begin{array}{l}\text { Razlozi zbog kojih izrazi nisu } \\
\text { prihvatljivi }\end{array}$ & Prihvaćeni izrazi \\
\hline Invalidi & $\begin{array}{l}\text { Okuplja ljude u jednu } \\
\text { istovrsnu kategoriju, } \\
\text { patronizira, ne odražava } \\
\text { individualnost, jednakost ili } \\
\text { dostojanstvo osoba s } \\
\text { invaliditetom. }\end{array}$ & $\begin{array}{l}\text { Osobe s } \\
\text { invaliditetom }\end{array}$ \\
\hline Hendikepirani & $\begin{array}{l}\text { Podrazumijeva da osobe s } \\
\text { invaliditetom trebaju } \\
\text { milosrde. }\end{array}$ & $\begin{array}{l}\text { Osobe s } \\
\text { invaliditetom }\end{array}$ \\
\hline $\begin{array}{l}\text { Priznaje svoj } \\
\text { invaliditet }\end{array}$ & $\begin{array}{l}\text { Invaliditet nije nešto što ljudi } \\
\text { priznaju ni što bi trebali } \\
\text { priznavati. }\end{array}$ & $\begin{array}{l}\text { Kaže da ima } \\
\text { invaliditet }\end{array}$ \\
\hline $\begin{array}{l}\text { Normalan, } \\
\text { zdrav, cjelovit }\end{array}$ & $\begin{array}{l}\text { Pojam normalan implicitno } \\
\text { znači da sve osobe koje } \\
\text { odstupaju od normalnog } \\
\text { razvoja pripadaju kategoriji } \\
\text { nenormalnih }\end{array}$ & $\begin{array}{l}\text { Osoba bez } \\
\text { invaliditeta }\end{array}$ \\
\hline $\begin{array}{l}\text { Gluh i nijem, } \\
\text { neverbalan, } \\
\text { slabo čuje, } \\
\text { gluhonijem }\end{array}$ & $\begin{array}{l}\text { Podrazumijeva da je osoba } \\
\text { hrabra zbog svog invaliditeta. } \\
\text { nesposobnost. Samo zato što } \\
\text { je neko gluh, ne znači da ne } \\
\text { može govoriti. }\end{array}$ & $\begin{array}{l}\text { Prevladao je svoj } \\
\text { invaliditet; } \\
\text { Uspješan; } \\
\text { govoria Ne može } \\
\text { goviti; Koristi } \\
\text { sintetički govor. }\end{array}$ \\
\hline Hrabar & $\begin{array}{l}\text { Osoba koja ne } \\
\text { godivan; }\end{array}$ \\
\hline
\end{tabular}




\begin{tabular}{|c|c|c|}
\hline $\begin{array}{l}\text { Privezan za } \\
\text { invalidska } \\
\text { kolica }\end{array}$ & $\begin{array}{l}\text { Invalidska kolica ne privezuju, } \\
\text { ona } \\
\text { ljude čine pokretljivima. }\end{array}$ & $\begin{array}{l}\text { Koristi invalidska } \\
\text { kolica; Korisnik } \\
\text { invalidskih kolica; } \\
\text { Osoba koja se služi } \\
\text { invalidskim } \\
\text { kolicima. }\end{array}$ \\
\hline $\begin{array}{l}\text { Bogalj, } \\
\text { obogaljen }\end{array}$ & $\begin{array}{l}\text { Engleska riječ „cripple“ dolazi } \\
\text { od staroengleske riječi koja } \\
\text { znači „puzati“, upotrebljava se } \\
\text { i kad želimo označiti nešto što } \\
\text { je inferiornije od nas, to je } \\
\text { dehumanizirajuće. }\end{array}$ & $\begin{array}{l}\text { Ima invalidno } \\
\text { stanje. }\end{array}$ \\
\hline Deformiran & $\begin{array}{l}\text { Podrazumijeva da je osoba } \\
\text { odvratna i čudna. }\end{array}$ & $\begin{array}{l}\text { Višestruki } \\
\text { invaliditet }\end{array}$ \\
\hline Nakaza, biljka & Dehumanizirajuće & Ozbiljan invaliditet \\
\hline $\begin{array}{l}\text { Ćaknut, } \\
\text { lud, psihopata, } \\
\text { manijak, luđak }\end{array}$ & $\begin{array}{l}\text { Stigmatizirajuće } \\
\text { Učvršćcuje negativne stereotipe }\end{array}$ & $\begin{array}{l}\text { Poremećaj u } \\
\text { ponašanju; } \\
\text { Emocionalni } \\
\text { invaliditet; } \\
\text { Osoba sa psiho- } \\
\text { socijalnim } \\
\text { invaliditetom; }\end{array}$ \\
\hline $\begin{array}{l}\text { Mentalno } \\
\text { defektan, spor, } \\
\text { priprost, kreten }\end{array}$ & $\begin{array}{l}\text { Podrazumijeva da osoba ne } \\
\text { može učiti. }\end{array}$ & $\begin{array}{l}\text { Razvojni } \\
\text { invaliditet; } \\
\text { Duševni }\end{array}$ \\
\hline Mongoloid & Smatra se uvredljivim. & $\begin{array}{l}\text { Osoba s } \\
\text { Downovim } \\
\text { sindromom }\end{array}$ \\
\hline $\begin{array}{l}\text { Oštećen pri } \\
\text { porodu }\end{array}$ & $\begin{array}{l}\text { Podrazumijeva da nešto nije } \\
\text { bilo u redu s porođajem. }\end{array}$ & Urođeni invaliditet \\
\hline Kepec & $\begin{array}{l}\text { Zastario izraz, smatra se } \\
\text { uvredljivim. }\end{array}$ & Osoba niskog stasa \\
\hline
\end{tabular}




\begin{tabular}{|l|l|l|}
\hline $\begin{array}{l}\text { Posebne } \\
\text { potrebe }\end{array}$ & $\begin{array}{l}\text { One nisu posebne za } \\
\text { određenu osobu, nego su } \\
\text { uobičajene. Izraz } \\
\text { podrazumijeva nešto što dijete }\end{array}$ & $\begin{array}{l}\text { Učenje uz } \\
\text { podsticaj; } \\
\text { Dodatne potrebe } \\
\text { za učenjem }\end{array}$ \\
\hline Retardiran & Stigmatizirajuće & Kasni u razvoju \\
\hline
\end{tabular}

U literaturi ne postoji jedinstven stav o tome koji je izraz najbolji. Izraz dijete sa posebnim potrebama je najneutralniji termin i ima najviše pristalica. Za bolje razumijevanje rečenog, u tabeli br. 2 prikazat ćemo primjer mlade žene koja koristi invalidska kolica i način razmišljanja ljudi u različitim vremenskim periodima koji jasno oslikavaju stav društvene sredine o invaliditetu.

Tabela br.2 Odnos prema invaliditetu u primjeru različitih modela

\begin{tabular}{|l|l|}
\hline $\begin{array}{l}\text { Model milosrđa } \\
\text { (XVI-XVIII st.) }\end{array}$ & $\begin{array}{l}\text { "Kakva šteta, ova prekrasna žena je vezana za } \\
\text { invalidska kolica, ona se više nikada neće moći } \\
\text { udati i imati djecu i brinuti se za svoju porodicu." }\end{array}$ \\
\hline $\begin{array}{l}\text { Medicinski model } \\
\text { (XVIII-XVIII st.) }\end{array}$ & $\begin{array}{l}\text { "O, ovo je jadna žena, ona je trebala otići kod } \\
\text { ljekara i razgovarati s njim, ako postoji terapija koja } \\
\text { bi joj mogla omogućiti da opet hoda, kao i svi } \\
\text { drugi." }\end{array}$ \\
\hline $\begin{array}{l}\text { Socijalni model } \\
\text { (IXX-XX st.) }\end{array}$ & $\begin{array}{l}\text { "Zajednica stvarno treba izgraditi rampe ispred } \\
\text { javnih objekata kako bi osobe koje žive u njoj } \\
\text { mogle sudjelovati u društvenom životu." }\end{array}$ \\
\hline $\begin{array}{l}\text { Inkluzivni model } \\
\text { utemeljen } \\
\text { pravima na } \\
\text { (XX-XXI st.) }\end{array}$ & $\begin{array}{l}\text { "Kada dobije posao, njezin poslodavac morat će joj } \\
\text { prilagoditi radni prostor. To je njeno pravo!" }\end{array}$ \\
\hline
\end{tabular}

U različitim zemljama, različitih kulturoloških i socijalnih stanja društva, proces uključivanja učenika $s$ posebnim potrebama u redovne osnovne škole ostvaruje se na različite načine. Prema istraživanjima najbrojnija djeca koja su integrirana u redovne škole su ona koja imaju usporen kognitivni razvoj. Implementacija nove inkluzivne orijentacije se postepeno uvodi u većem broju zemalja. Promjene u specijalnom odgoju i 
obrazovanju u susjednim državama kao što je Hrvatska, uslijedile su 80-ih godina.

Slovenija je prema izvještaju UNICEF-a 1997. godine o uspješnosti integracije djece sa poteškoćama u razvoju u redovne škole po međunarodnim standardima najvjernije slijedila ideju inkluzivnog obrazovanja. Ona je 1996. godine usvojila pet zakona koji na novi način tretiraju obrazovanje djece $s$ posebnom potrebama. Država je dala podsticaj integraciji djece sa razvojnim teškoćama u redovne škole i povoljna zakonska rješenja koja se tiču obuke nastavnika, adaptacije programa, primjene adekvatnih metoda, dodatne pomoći učenicima, izrade IEP-a, obuke roditelja itd.

Makedonija je u fazi pripreme za inkluziju, dok se u Srbiji još uvijek isključivo primjenjuje segregacijski način školovanja $s$ naglaskom na diferenciju nastave.

U Austriji je obavezno devetogodišnje osnovno obrazovanje koje započinje sa šest godina, a osnovna škola traje četiri godine (Volksschule-V). Ukoliko nije moguća integracija u redovne škole, onda djeca sa poteškoće u razvoju pohađaju specijalne škole, ovisno o njihovoj poteškoći (Sonderschule-SS). Kao izravni nastavak specijalne osnovne škole ustrojena je i specijalna škola na nivou srednjeg obrazovanja (Sonderschule). Srednja specijalna škola omogućuje izbor zanimanja ili nastavak školovanja na višem nivou, ovisno o kategoriji ometenosti.

U Češkoj se obrazovanje djece sa smetnjama u razvoju realizira u osnovnim (specijalni zakladny skoly) i srednjim specijalnim školama (specijalni sredni školy). Učenici koji se ne mogu integrirati u redovne i specijalne škole pohađaju, tzv zvlasni školy. Oni koji imaju teže oblike onesposobljenja pohađaju posebne pomoćne škole, koje traju deset godina, a u njima savladavaju osnovne navike potrebne za život.

U Velikoj Britaniji Vlada je 1981. godine usvojila zvaničnu politiku integracije djece ometene u razvoju u redovne škole koja je pretrpjela brojne zakonodavne modifikacije. Zakon je predvidio dva uslova za integraciju u redovne škole: da su roditelji saglasni i da smještaj u redovnoj školi ne ometa obrazovanje ostale djece. 
U Holandiji se opstanak specijalnih škola vidi u okviru kontinuuma obrazovnih usluga koji se pruža na različitim mjestima, dok se u Engleskoj smatra da se one trebaju postepeno smanjivati i povezivati sa redovnom školom.

U drugim evropskim zemljama, poput Italije, Francuske, Španije, Engleske, integracija se provodi na svim nivoima školovanja, profesionalnog osposobljavanja i zapošljavanja.

Za razliku od integracije u kojoj se okolina privikava na prisustvo osobe $s$ invaliditetom, $u$ inkluziji osoba $s$ invaliditetom se prihvaća, respektuje i osnažuje da ravnopravno sudjeluje u svim segmentima života.

U protekloj deceniji XXI stoljeća sve manje su prisutni degradirajući termini za djecu sa teškoćama u razvoju, a umjesto njih se koristi pojam osobe s posebnim potrebama. Ovaj pojam je posljedica sve prisutnije inkluzije, koja podrazumijeva ravnopravnu participaciju ovakve djece u obrazovanju i socijalnom životu. Štaviše, ove sintagme su upotrebljive i korisne za označavanje posebnih obrazovnih potreba darovite djece, jer obuhvataju i potrebu za podrškom razvoju talenta i ličnosti nadarene djece. Različiti konceptualni modeli podupiru društvenu percepciju invalidnosti i utiču na intervencije uključivanja osoba sa invaliditetom, kao ravnopravnog socijalnog bića, u školovanju, zapošljavanju, radu, kulturnim aktivnostima, sportu, političkom djelovanju i sl.

U savremenoj pedagoškoj literaturi pod sintagmom djeca sa posebnim potrebama podrazumijevamo djecu koja ekstremno odstupaju od prosječnog fizičkog, kognitivnog ili socijalnog razvoja.

„To odstupanje nije podjednako u svim područjima, a može se javiti u obliku natprosječnog ili ubrzanog razvoja, ispodprosječnog ili usporenog, nepravilnog ili čak ograničenog razvoja." (Zovko, 1999: 369).

U kontekstu takvog razmišljanja Zovko (ibid) djecu sa posebnim potrebama koja odstupaja od prosječnog razvoja dijeli na sljedeće kategorije:

- djeca sa posebnim potrebama koja odstupaju u smjeru natprosječnog razvoja; 
- djeca sa posebnim potrebama koja imaju smetnje u razvoju;

- djeca sa posebnim potrebama koja imaju teškoće u učenju.

- Djeca koja odstupaju u smjeru natprosječnog razvoja

Jedan od razloga natprosječnih sposobnosti kod djece se veže za nasljedni faktor, starost roditelja i redoslijed rađanja djeteta u porodici. Uticaj sredinskog faktora, kao i faktora samoaktualizacije su omogućili povoljne uslove za razvoj natprosječnih sposobnosti kod djece. Odstupanje u smjeru natprosječnog razvoja ispoljava se na tri načina:

darovitost - temelji se na intelektualnim sposobnostima mjerenim testovima inteligencije kao i uvažavanju drugih sposobnosti koje imaju tri bitna obilježja: natprosječnu sposobnost, predanost zadatku i kreativnost (Renzuli, 1979);

kreativnost - obilježava je sposobnost nalaženja originalnih rješenja modelom strukture intelekta, a očituje se razmišljanjem na različite načine i u različitim smjerovima. Bitnim svojstvima mnogi smatraju originalnost, fleksibilnost, motivaciju i fluentnost. Kreativne osobe vide stvari u novom svjetlu i rješavaju problem na nov i neobičan način. Kvaščev (1976:259) navodi sljedeće osobine ličnosti koje su Cattell i Butcher (1968) izdvojili kao kreativne: inteligencija, emocionalna stabilnost, nezavisnost, dominantnost, radikalizam, dovoljnost samom sebi, kontroliranost i društvena preciznost, sklonost rizici, spontanost, neinhibiranost, imaginativnost, samo uvjerenost, samostalnost u donošenju odluka i radoznalost.

talentiranost - obično se odnosi samo na jedno područje ljudske aktivnosti. Ona involvira visokorazvijenu kreativnost i motivaciju za područje matematike i jezika, umjetničkog izražavanja, psiho-socijalno područje i psiho-motoričko područje.

$\mathrm{Ne}$ postoje standardni IQ nivo za intelektualnu darovitost, ali Hollingworth Centar za darovitu djecu je 1994. godine predložio sljedeće granice IQ:

- $\quad$ blago darovit - IQ između 115 i 129 
- $\quad$ umjereno darovit - IQ između 130 i 144

- jako darovit - IQ između 145 i 159

- $\quad$ izvanredno darovit - IQ viši od 160

Djeca koja odstupaju u smjeru ispodprosječnog razvoja

Ovo odstupanje obično nazivamo smetnjama u razvoju. Spektar tih odstupanja je vrlo širok, a njihova frekvencija u populaciji osjetno varira. Prema klasifikaciji funkcionalnog poremećaja djecu koja odstupaju u smjeru ispodprosječnog razvoja možemo podijeliti u šest kategorija:

- Oštećenje senzornih funkcija

- oštećenja vida: sljepoća i slabovidnost;

- oštećenja sluha: gluhoća i nagluhost;

- senzorni poremećaji taktilne osjetljivosti, bola, dodira, kretanja i ravnoteže.

- Poremećaji pažnje, kognitivnih, intelektualnih i perceptivnih funkcija

- poremećaji govorno-glasovne-jezičke komunikacije;

- $\quad$ specifične teškoće u učenju;

- mentalna retardacija, koja može biti laka (IQ 50-69), umjerena (IQ 35-49), teža (IQ 20-34) teška (IQ 0-20);

- poremećaj sposobnosti učenja;

- poremećaj pažnje;

- okolomotorni perceptivni poremećaj

- Poremećaji kontrole mišića

- tjelesni invaliditet (motorička oštećenja), uključujući: lokomotorna oštećenja, sustavnu leziju, oštećenje centralnog nervnog sistema;

- oštećenja perifernog nervnog sistema;

- oštećenja izazvana hroničnim bolestima ili drugim tjelesnim onesposobljenjima. 
- Hronični oblici bolesti

- metabolički i fiziološki poremećaji (hipo i hipertireoidizam, galaktosemija, fenilketonurija, astma, juvenilni dijabetes, urođene bolesti srce, zavisnost od aparata za održavanje života.

- Emocionalni dječiji poremećaji

- poremećaji u ponašanju uvjetovani organskim faktorima ili progredirajućim

- psiho-patološkim stanjima;

- Dječije psihoze, emocionalne promjene izazvane oštećenjem nervnog sistema.

- Djeca sa višestrukim smetnjama u razvoju

- Djeca sa teškoćama u učenju

Teškoće u učenju podrazumijevaju da je govorna komunikacija otežana ili nije uopće moguća. Ova kategorija, također, uključuje specifične teškoće u učenju u jednom od sljedećih područja:

- čitanje (disleksija, aleksija) - nemogućnost čitanja i razumijevanja pročitanog kao i prisjećanje izgovorenih riječi;

- pisanje (disgrafija, agrafija) - nemogućnost pisanja ili razumijevanje napisanog kao i razumijevanja zbog pogrešnog percipiranja slova;

- i/ili računanje (diskalkulija, akalkulija) - problem nepoznavanja brojeva i svhaćanja temeljnih matematičkih pojmova;

- slaba pažnja i hiperaktivnost;

- socijalno-motorič̌ki i drugi perceptivni deficiti (teškoće koncentracije, nezrela kontrola sitnih mišića, teškoće u dekodiranju značenja riječi)

Uzroci odstupanja i nepravilnosti u razvoju mogu biti uslovljeni razvojem genetskih, organskih i socijalnih faktora. Potpuniji pregled općih uzroka i mogućih posljedica teškoća u razvoju, daje Svjetska zdravstvena organizacija (WHO, 1985) u kojem se među uzročnike ubrajaju: bolest i okolina u kojoj se ona pojavila, te stavovi društva i zahtjevi koje društvo 
pred njega postavlja" (prema, Biondić 1993:26). Uzročni faktori koji se mogu dovesti u vezu sa teškoćama u učenju su usko povezani sa mentalnom insuficijencijom djece. mentalna insuficijencija ima različitu etiologiju. Fulan (1991:114) navodi jednu od etioloških klasifikacija:

- zaostalost zbog infektivnih bolesti ( npr. meningitisa, šarlaha);

- zaostalost izazvana intoksikacijama ( alkohol, droge);

- zaostalost zbog vanjskih povreda;

- zaostalost zbog poremećaja metabolizma;

- zaostalost zbog tumora;

- zaostalost zbog štetnih prenatalnih uticaja;

- zaostalost izazvana psihičkim traumama;

- genetski ( nasljedni uzroci);

- kranijalne ozljede;

- oštećenje osjetilnog aparata;

- konvulzivna stanja ( npr. epilepsija);

- psihijatrijska stanja( psihička trauma);

- motorička disfunkcija.

Posljedice oštećenja mogu se spriječiti upotrebom više oblika prevencije kao što su:

- primarna prevencija u kojoj se nastoje suzbiti faktori koji su uzrok oštećenja;

- sekundarna prevencija se organizira nakon što se pojavilo oštećenje, a svrha joj je sprječavanje daljeg širenja;

- tercijarna prevencija se provodi nakon što nastupi funkcionalno somatsko ili mentalno ograničenje koje se ne može na drugi način ispraviti. 


\section{Razvoj inkluzivnog obrazovanja u Bosni i Hercegovini}

Prema procjenama WHO i WB otprilike $15 \%$ svjetske populacije danas ima neku vrstu invaliditeta od čega je 200 milijuna djece rođeno sa oštećenjem ili su onesposobljena tokom djetinjstva (United Nations, 2011). Kada govorimo o Bosni i Hercegovini, istraživanja višestrukih pokazatelja (MICS) iz 2006. godine ukazuju da više od 10\% stanovništva $\mathrm{BiH}$ ima problema sa vidom, sluhom, govorom, pamćenjem ili otežanim kretanjem. Isti izvor navodi da 6,5\% djece između 2 i 9 godina, ima neki vid poteškoće u fizičkom, osjetilnom ili mentalnom razvoju.

Historijski gledano, briga i zaštita djece su dobile na značaju tek poslije Drugog svjetskog rata, kada je u sistemu bivše Jugoslavije, pa i u $\mathrm{BiH}$, omogućeno školovanje djece i omladine sa onesposobljenjem u specijalnim odgojno-obrazovnim ustanovama. Prvi zakonski akt u kojem su postavljeni osnovi razvoja specijalnog školstva je bio Zakon o domovima i školama za djecu sa umnim i tjelesnim nedostacima. Ovaj zakon je donesen 1947. godine i važio je do 1964. godine kada je donesen novi zakon o specijalnim školama. On propisuje stjecanje naobrazbe za djecu ometenu u fizičkom i psihičkom razvoju i osposobljavanje za samostalni život u posebnim stručnim ustanovama: specijalne predškolske ustanove, specijalne škole, specijalna odjeljenja pri redovnim školama i odjeljenja u sastavu zdravstvenih i socijalnih ustanova. Nastava se izvodila po posebnim nastavnim planovima i programima koji su se za svaku vrstu specijalne osnovne škole posebno propisivali.

Isti zakon je regulirao pitanje školovanja djece van svog prebivališta i njihovo izdržavanje, a s tim u vezi i smještaj djece za vrijeme školovanja“ (Šarenac, 2003:14). Tako su djeca sa lakšim i težim oblicima onesposobljenja u najranijoj dobi odvojena od porodice i isključena iz lokalne zajednice. Socijalni kontakt je bio ograničen samo na stručno osoblje koje je bilo usmjereno na ozdravljenje, dok su potrebe za sigurnošću, ljubavlju, pripadanjem, aktivnošću, učenjem, nezavisnošću, samoostvarenjem, samoaktualizacijom kao i mnoge druge koje Maslov (1908-1970) ističe, zanemarene. 
U Bosni i Hercegovini stanje specijalnog školstva se nije znatno mijenjao sve do početka rata (1992), kada je zbog ratnih dejstava većina ovih škola uništena, a djeca raseljena i prognana. Velik broj trajnih oštećenja nastalih u vrijeme rata kod djece se mogao na vrijeme spriječiti, jer su nastala kao posljedica neuhranjenosti, nesreće, nasilja, traume, rata, siromaštva ili bolesti. Iz jedinstvenog i visokocentraliziranog obrazovnog prijeratnog sistema, u periodu od 1992. do 1995. godine dolazi do decentralizacije i podjele na tri obrazovne politike. „Na teritoriji koju su kontrolirali bosanski Hrvati korišten je nastavni plan i program i udžbenici Republike Hrvatske. Na teritoriji koju su kontrolirali bosanski Srbi korišten je nastavni plan i program i udžbenici Republike Srbije. Na teritoriji koju su kontrolirali Bošnjaci u periodu 1992/93. korišten je nastavni plan i program Republike Bosne i Hercegovine, koji je 1994. godine izmijenjen i dopunjen. Iako su u periodu rata uslovi života i rada bili veoma teški i često rizični, nastavni proces se u skoro svim dijelovima zemlje kontinuirano odvijao" (ICESCR,2004:110). Kao posljedica podjele, sve do početka školske 2003/2004. godine, u BiH su egzistirale 52 škole pod jednim krovom, koje su radile po različitim nastavnim planovima i programima baziranim na nacionalnoj osnovi.

$\mathrm{Na}$ temelju Dejtonskog mirovnog sporazuma (1995) doneseni su novi zakoni o osnovnom odgoju i obrazovanju u Federaciji BiH i Republici Srpskoj. U Federaciji Bosne i Hercegovine obrazovanje se dalje decentralizira, a nadležnost nad obrazovanjem se prenosi na deset kantona. U pet kantona sa bošnjačkom većinom je na snazi bosanski nastavni plan i program, u tri kantona sa hrvatskom većinom hrvatski nastavni plan i program, a u dva mješovita kantona, koja su efektivno podijeljena između ove dvije grupe, dolazi do mješovitog nastavnog plana i programa. Upravna vlast u Republici Srpskoj obrazovanje centralizira na entitetskom nivou gdje je na snazi srpski nastavni plan i program. Iako su nastale pozitivne promjene u sistemu obrazovanja nakon potpisivanja Dejtona, složena politička situacija stavila je u drugi plan temeljna prava, ne samo djece sa poteškoćama u razvoju, nego i svakog drugog djeteta koje živi na prostoru BiH. Naime, djeci je i dalje onemogućen pristup bilo kojoj školi, sve dok oni i njihovi roditelji ne prihvate da se nastava pohađa prema 
dominantnom nastavnom planu i programu sa svim njegovim nacionalnim predispozicijama

(jezik, pismo, kultura itd.).

Kako bi se prevazišao ovaj problem, Okvirni zakon o osnovnom i srednjem obrazovanju u Bosni i Hercegovini 2003. godine propisuje uvođenje zajedničke jezgre nastavnih planova i programa ili nacionalne grupe predmeta u nastavne planove i programe. Zajednička jezgra treba da osigura kvalitetnu i objektivnu informaciju o historijskim, geografskim, ekonomskim, jezičkim, etničkim, kulturnim i drugim posebnostima važnim za konstitutivne narode i nacionalne manjine u BiH. „Postojeća zajednička jezgra nastavnih planova i programa (ZJNPP-a) u Bosni i Hercegovini za osnovnu školu i gimnaziju utvrđena je 2003. godine na temelju tada važećih NPP-a za osmogodišnju osnovnu školu u Federaciji $\mathrm{BiH}$ i devetogodišnju osnovnu školu u Republici Srpskoj. Zajednička jezgra je isključivo usmjerena na predmete i njihove programske sadržaje koji su prepoznati kao zajednički. Sporazum o zajedničkoj jezgri cjelovitih razvojnih programa za rad u predškolskim ustanovama donesen je 2008, a u primjeni je od 2009/10. godine“ (APOSO,2011:19). Uvođenjem zajedničke jezgre nastoje se definirati standardi u obrazovanju radi osiguranja koherentnosti, prohodnosti i kompatibilnosti obrazovnog sistema, ne samo na teritoriji $\mathrm{BiH}$ nego i u EU i šire. Postojeća zajednička jezgra donijela je izvjesne pozitivne promjene, jer omogućuje svoj djeci, bez obzira na jezičku i kulturnu pripadnost, slobodan pristup i izbor škole, te osigurala prohodnost učenika na cijelom prostoru $\mathrm{BiH}$.

Od integracije do inkluzije u $\mathrm{BiH}$

Donošenjem Okvirnog zakona o osnovnom i srednjem obrazovanju u Bosni i Hercegovini ("Službeni glasnik BiH" broj 18/03 ), regulirano je uključivanje djece $s$ razvojnim smetnjama u redovne i specijalne škole. Proces integracije zahtijeva sljedeće procedure koje započinju već pri samom upisu djeteta u školu:

Procjena zdravstvene sposobnosti djeteta koju utvrđuje pedijatar na osnovu čega izdaje ljekarsko uvjerenje za pohađanje škole; 
Procjena odgojno-obrazovnog statusa i zrelosti djeteta za polazak u školu koju vrši školska komisija u sastavu pedagog, psiholog i nastavnik razredne nastave. Ukoliko komisija uoči da dijete ima poteškoće u razvoju, škola je dužna pribaviti mišljenje stručnog lica kao što je oligofrenolog ili logoped;

$\mathrm{Na}$ osnovu procjene i mišljenja stručnog lica (oligofrenologa ili logopeda) obezbjeđuje se inkluzija djece sa lakšim mentalnim i fizičkim smetnjama u razvoju u redovnu školu, $s$ tim da se učeniku obezbijedi posebna stručna pomoć koju pruža defektolog-logoped. U školama gdje nema defektologalogopeda stručnu pomoć pruža pedagoško-psihološka služba i druga stručna lica;

Dijete za koga stručno lice sumnja da ima teže i teške oblike onesposobljenja ex officio (lat.), po službenoj dužnosti se upućuje na utvrđivanje stepena i vrste ometenosti. To utvrđuje stručna komisija koju formira centar za socijalni rad na nivou općine;

$\mathrm{Na}$ osnovu kriterija determiniranih procedurom prvostepena stručna komisija u sastavu od 6 članova: klinički psiholog, pedijatar ili školski ljekar, neuropsihijatar, dva specijalna edukatora (oligofrenopedagog i logoped) i socijalni radnik utvrđuje stepen onesposobljenja;

Ukoliko roditelj nije zadovoljan nalazom prvostepene komisije, može se obratiti drugostepenoj komisiji za reviziju nalaza i donošenje konačnog mišljenja. Komisija za kategorizaciju i procjenu sposobnosti osoba $s$ teškoćama u razvoju je formira po kantonima, dok je drugostepena komisija na nivou Republike Srpske i Federacije Bosne i Hercegovine;

$\mathrm{Na}$ osnovu rješenja komisije, kojim je utvrđena vrsta i stepen ometenosti u razvoju, djeca sa težim i teškim smetnjama stiču osnovno obrazovanje i vaspitanje u specijalnim školama ili specijalnim odjeljenjima.

Okvirni zakon o osnovnoj i srednjoj školi u $\mathrm{BiH}$ omogućuje sljedeće vidove odgoja i obrazovanja djece sa teškoćama u razvoju i učenju:

- punu odgojno-obrazovnu integraciju djece sa poteškoćama u razvoju u redovna odjeljenja;

- parcijalnu integraciju u odjeljenja djece sa poteškoćama u razvoju u okviru redovne škole; 
- potpunu separaciju koja uključuje djecu s teškoćama u razvoju u specijalizirane posebne institucije ili škole.

Potpuna integracija se odnosi na učenike graničnih intelektualnih sposobnosti (IQ=70-79). Ovi učenici se obrazuju po prilagođenom programu u uvjetima potpune integracije. Smanjen je opseg nastavne građe i prilagođene su metode poučavanja nastavnom sadržaju. Pojačan je rad i nadzor pedagoga, psihologa i defektologa. Učenici s lakim mentalnim teškoćama koji nemaju izrazito naglašene razvojne poteškoće, školuju se u sistemu djelomične integracije $\mathrm{u}$ posebnim odjeljenjima u kojima savladavaju nastavne sadržaje maternjeg jezika, matematike i prirode $\mathrm{i}$ društva, dok nastavne sadržaje likovne i muzičke kulture, tehničkog i tjelesnog odgoja savladavaju u redovnim razredima. Djeca sa izražajnijim smetnjama u psiho-fizičkom razvoju pohađaju nastavu u posebnim odjeljenjima u redovnoj školi po prilagođenom NPP-u, gdje je, pored edukacije, potrebna rehabilitacija i resocijalizacija. Odgojno-obrazovni rad se realizira prema prilagođenom nastavnom planu kojeg implementira defektolog individualno ili u posebnom specijalnom odjeljenju. Ukoliko komisija procijeni da se radi o djetetu sa težim onesposobljenjem, ono se, u zavisnosti od vida i stepena, upućuje u specijalne škole ili zavode, koji još uvijek postoje u našoj zemlji.

Pedagoškim standardima i normativima utvrđeni su kriteriji za implementaciju inkluzivnog odgoja i obrazovanja u redovnim školama. Neka od pravila koja su škole dužne da primjenjuju prema ovim standardima su:

- najviše troje djece sa posebnim potrebama može se integrirati u isto redovno odjeljenje;

- sva djeca koja pripadaju kategoriji djeteta sa posebnim potrebama moraju proći izvjesnu kategorizaciju i imati posebnu dokumentaciju;

- za školsku djecu sa senzornim i motoričkim oštećenjima (vidnim, slušnim i fizičkim), koja su potpuno integrirana u redovne razrede, organizira se na kraju redovnog školskog dana produženi stručni postupak u grupe od šest do deset učenika; 
- učenici s lakom mentalnom retardacijom i bez utjecajnih teškoća u razvoju obrazuju se po sistemu parcijalne integracije u posebnim razredima od 5 do 9 učenika, zavisno od vrste i stepena razvojnih teškoća. Tu uče maternji jezik, matematiku i prirodu, dok istovremeno likovnu, muzičku, tehničku i tjelesnu kulturu imaju u redovnim razredima;

- djeca koja su kategorisana ne mogu da ponavljanju razred;

- za svako integrirano dijete u redovnom odjeljenju izrađuje se individualni program podrške (IPP) koji podrazumijeva smanjenje intenziteta i obima školskog program. Program je obogaćen posebnim metodama, didaktičkim sredstvima i opremom;

- NPP za djecu sa posebnim potrebama implementiraju i defektolozi i nastavnici;

- svaka škola koja ima djecu sa posebnim potrebama ima i pomoć stručnog tima sastavljenog od pedagoga, psihologa, logopeda, defektologa i socijalnog radnika. Stručni tim analizira postojeću dokumentaciju, radi na prilagođavanju kurikuluma, razvija individualne programe podrške (IPP), predlaže metode i tehnike rada, prati implementaciju liječenja i evaluira IPP;

- osim djeteta, i roditelji imaju pravo na edukaciju od strane mobilnog tima, kako bi mogli ostvariti partnersku ulogu sa školom u smislu bolje pomoći i podrške u toku djetetovog školovanja;

- inkluzija uključuje i podučavanje sve djece na razumijevanje i prihvatanje razlike bez obzira na porijeklo, boju, pol, etnicitet, jezik, nacionalnost, socijalno porijeklo, religiju, invaliditet, osobinu, rođenje ili drugi status;

- $\quad \mathrm{u}$ inkluzivnim odjeljenjima planiran je asistent u nastavi, kao pomoćnik nastavniku u redovnom odjeljenju;

- djeci sa umanjenim kognitivnim i fizičkim sposobnostima neophodno je obezbijediti fizikalni, logopedski i defektološki tretman u cilju ranog pomaganja i postizanja što boljih rezultata; 
- za poboljšanje kvaliteta zaštite djece $s$ posebnim potrebama neophodno je permanentno informirati javnost o potrebama djece i uticati na promjenu svijesti kako bi se u potpunosti eliminirala obrazovna isključenost;

- za djecu koja zbog bolesti duži vremenski period ne mogu pohađati nastavu, organizira se tzv. nastava u kući;

- za djecu koja su na duži period hospitalizirana (na primjer na onkologiji, psihijatriji ili drugim odjelima) također se organiziraju i dovode učitelji i stručni suradnici iz najbliže osnovne škole;

- opremanje škole potrebnim didaktičkim i rehabilitacijskim sredstvima i pomagalima je jedan od uvjeta koje škola mora da ispunjava;

- osigurava se pristup školskim prostorijama ( arhitektonske barijere, prijevoz).

\section{Individualni program podrške}

Individualni program podrške (IPP) je od suštinskog značaja za razvoj inkluznog programa. On predstavlja dokument kojim se podstiču i objedinjuju sve aktivnosti u školi. Usmjeren je na podršku djetetu kako bi bili ostvareni odgojno-obrazovni ciljevi, koji su u skladu sa njegovim intelektualnim i razvojnim mogućnostima. IPP se izrađuje pojedinačno za svako dijete kome je potreban podsticaj. Prema Rajoviću (2009) IPP sadrži sljedeće komponente:

- detaljan opis aktuelnog funkcioniranja djeteta i socio-kulturne situacije porodice u kojoj dijete živi;

- razvojni status djeteta (opis aktuelnog nivoa funkcioniranja djeteta $u$ cjelini, a zatim i po oblastima razvoja - saznajnog, emocionalnog, fizičkog i socijalnog);

- očuvani potencijali djeteta (individualne karakteristike djeteta: sklonosti, sposobnosti, potrebe, interesovanja);

- vrstu, stepen težine, primarne i sekundarne posljedice razvojnih teškoća, uticaj razvojne teškoće na ostvarivanje obrazovnih i odgojnih 
ciljeva (uspostavljenje radnih navika, emocionalne stabilnosti, socijalizacije);

- oblasti u kojima je potrebna podrška (oblasti u kojima sporije napreduje);

- oblici podrške, način izvođenja i nositelje podrške, vremenske okvire;

- strukturu tima i zadatke pojedinih članova, vremenski utvrđene obaveze;

- način praćenja postavljenih ciljeva i indikacije za reviziju IPP;

- način vrednovanja postavljenih zadataka, način obavještavanje ostalih članova kolektiva;

- prikaz trenutnog nivoa postignuća, dobijenog na osnovu podataka sakupljenih tokom procesa procjenjivanja;

- mjesto realizacije IPP-a (škola, učionica, servisni centar...);

Ne postoji jedinstveni prilagođeni nastavni plan i program koji bi se mogao primjenjivati za svu djecu $s$ teškoćama u razvoju. Planiranje, programiranje $\mathrm{i}$ rad sa svakim pojedinim djetetom treba biti individualiziran u skladu sa razvojnim potrebama djeteta. Međutim, samo pojedini učenici s teškoćama u razvoju mogu ostvarivati napredak (u svim ili pojedinim školskim predmetima) zajedno sa svojim vršnjacima i to samo u nekoj mjeri. Ne postoji učenik koji se ne može obrazovati, poučavati ili obučavati prema njegovim individualnim razvojnim kapacitetima. Razvijanjem i implementiranjem prilagođenih programa treba odrediti nivo sposobnosti i znanja učenika za svaki pojedini predmet; postaviti kratkoročne $\mathrm{i}$ godišnje obrazovne ciljeve, utvrditi posebne potrebe djeteta i načine kako ih zadovoljiti, odrediti nivo sudjelovanja učenika u aktivnostima redovnog programa, utvrditi trajanje individualne podrške i objektivne kriterije, sredstva i metode za evaluiranje i educiranje, te navesti stručne profile nadležne za osmišljavanje, realiziranje, evaluiranje i eventualno modificiranje takvih programa $(\mathrm{OECD} / \mathrm{H}, 2007)$.

Individualni program podrške (IPP) je osnovni alat u obrazovanju djece $s$ posebnim potrebama, posebno za oživotvorenje inkluzije. On je pisani i 
radni dokument koji nastaje kao rezultat procjene individualnih potencijala i potreba učenika, te opisuje posebne obrazovne ciljeve i usluge. Baziran je na detaljnoj procjeni učenikovih sposobnosti, interesa i potreba. Identificira posebne ciljeve i očekivanja i objašnjava kako će obrazovni program pomoći djetetu da postigne te ciljeve i očekivanja postavljena $u$ programu. Posebni obrazovni programi i usluge se, nadalje, po potrebi modificiraju kroz kontinuiranu procjenu. (OECD/BIH, 2007).

Obim prilagodbe i podrške varira u odnosu na individualne obrazovne potrebe svakog učenika. Učenicima sa složenijim potrebama bit će nužno značajnije prilagođavanje obrazovnog programa, koje je potrebno uraditi na nivou:

- percepcije: prilagođavanje sredstava za predočavanje, tiska, prostora za čitanje/pisanje, isticanja u tekstu;

- spoznaje: uvođenje u postupak, planiranje, sažimanje, pojednostavljivanje teksta, shematski prikazi;

- govora: prilagođavanje izražajnosti, razgovjetnosti, razumljivosti, govorno usmjeravanje pažnje;

- zahtjeva: samostalnost, vrijeme i način rada, aktivnost, provjeravanje.

Pri odabiru primjerenog didaktičko-metodičkog pristupa potrebno je procijeniti dječije sposobnosti, znanje, interese i posebne potrebe. Ivančić i Stančić (2002:142) naglašavaju da je naročito važno procijeniti sljedeće sposobnosti djeteta: slušanje, usmeno izražavanje, prostorno i vremensko snalaženje, rukovanje sredstvima za rad, sticanje radnih navika, čitanje, pismeno izražavanje, računanje i geometrijsko predočavanje.

\section{Organizacija specijalnog školstva u BiH}

„Reformom obrazovnog sistema 2003. godine usvojen je i novi zakon o inkluzivnom obrazovanju djece, koji daje mogućnost djeci sa posebnim potrebama da u cijelosti pravilno razviju svoje sposobnosti. Iako je od donošenja ovog zakona protekla skoro decenija, specijalne škole u $\mathrm{BiH}$ su i dalje otvorene" (UNESCO, 1996). Pored organizacijskih oblika rada u redovnim i specijalnim školama, egzistiraju i tzv. dnevni centri za 
rehabilitaciju u kojima se provode programi za djecu različitih oštećenja kognitivnog i adaptivnog funkcioniranja na nivou umjerene i teže mentalne zaostalosti. Djeca sa teškim onesposobljenjem su smještena $u$ domove i nisu uključena ni u kakav vid obrazovanja. Ovu kategoriju djece stručne službe u obrazovnom sektoru ne smatraju sposobnim za edukaciju već samo za osposobljavanje.

\section{ZAKLJUČAK}

Diskriminacija prema osobama koje imaju poteškoće u razvoju prisutna je kroz cijeli ljudski razvoj. Najbolji dokaz su grčki i rimski zakoni prema kojima je bilo dozvoljeno ubijanje djece i osoba s mentalnim i drugim teškoćama u razvoju. Njihov najveći grijeh je bio to što nisu mogli raditi koliko i drugi i tako doprinositi društvu. U XX stojeću dolazi do raznih pokreta koji zagovaraju poštivanje ljudskih prava. Organizacija Ujedinjenih Nacija usvojila je više od 40 dokumenata koji štite prava djece sa onesposobljenjem. Jedan od tih dokumenta je donesen od strane Glavne skupštine UN-a na 48. zasjedanju 1993. godine pod nazivom "Standardna pravila za izjednačavanje mogućnosti osoba s hendikepom". Ovaj dokument sadrži 22 pravila koja obuhvataju sva područja života uključujući: zdravstvenu zaštitu i rehabilitaciju, odgoj i obrazovanje, pomoćne službe i zapošljavanje, socijalnu sigurnost i kulturu, rekreaciju, sport i religiju. Kada govorimo o djeci u Bosni i Hercegovini, pravno gledano, svima su pružene jednake mogućnosti za korištenje zaštite i prava na cijeloj teritoriji države. Ovo pravo proizlazi iz Konvencija o pravima djeteta koja je uvrštena u Ustav Bosne i Hercegovine. Ono predstavlja dječiji univerzalni zakon koji obavezuje našu državu da preduzme sve mjere i kreira takav društveni ambijent koji će omogućiti jačanje položaja i zaštite prava, ne samo djece sa poteškoćama u razvoju, nego i djecu koja su na bilo koji način isključena, marginalizirana, etiketirana ili diskriminirana iz društva. Prevencija mentalnih poremećaja i unapređenje mentalnog zdravlja od ključnog je značaja za svaku zajednicu. Da bi se smanjio teret mentalnih poremećaja, neophodno je da se veća pažnja usmjeri na prevenciju i unapređenje mentalnog zdravlja u okviru nacionalne politike, legislative, upravljanja i financiranja. Iako strategija prevencije mentalnog 
zdravlja u $\mathrm{BiH}$ nije obuhvatila obrazovni sektor, mišljenja smo da implementacija inkluzije u velikoj mjeri može uticati na adekvatno stimuliranje zdravog razvoja djece u prevenciji spektra mentalnih bolesti. Pravo na zdravlje i zdravstvenu zaštitu je univerzalno i neprikosnoveno pravo svakog čovjeka, bez obzira na njegovu vjersku, nacionalnu i rasnu pripadnost. Ono ne može biti ograničeno političkim, financijskim ili geografskim barijerama.

\section{Literatura:}

1. Biondić, I. (1993), Integrativna pedagogija, Školske novine, Zagreb, str. 26, 74 .

2. Beker, K., (2010), Pravo da donesem odluku,"Grafos internacional“ Pančevo.

3. Furlan, I., (1991), Čovjekov psihički razvoj, Školska knjiga, Zagreb, str. 114.

4. Gleeson, B. (1999), Geographies of Disability. London: Routledge, pp. 160.

5. Gudjons, H. (1993), Pedagogija - temeljna znanja, Educa, Zagreb, str, 253Harris, J. C. (2006), Intellectual disability: Understanding its development, causes, classification, evaluation, and treatment. Oxford: Oxford University Press.

6. Hegarty. S., Pocklingron, K \& Lucas, D., (1984), Educating Pupils with special needs in ordinary schools, NEFER-Nelson publishing Co, pp 68.

7. Jaeger, P.T., Bowman C.A. (2005), Understanding disability: inclusion, access, diversity, and civil rights. Westport: Greenwood Publishing Group, Inc, str. 29.

8. Rački, J., (1997), Teorija profesionalne rehabilitacije osoba s invaliditetom, Fakultet za defektologiju, Zagreb, str. 38.

9. Šimleša, P., (1973), Pedagogija, Pedagoško-književni zbor, II izdanje, Zagreb Žunić, Z., (2001), Profesionalnom rehabilitacijom u 21. stoljeće, Državni zavod za zaštitu obitelji, materinstva i mladeži, Zagreb, str. 19, 25.

10. Spahić,M., (1996), Povijest islama, El-Hidaja, Sarajevo. 
11. Quinn, G. i Degener, T. (2002), The moral authority for change: human rights values and the worldwide process of disability reform, New York.

12. Uhlendorff, U., ( 2009), Handbuch Erziehungswissenschaft (Hrsg.: Böhm,W., Frost, U., Ladenthin, V., Mertens, G.), Band III, Teilbereich 6, Umwelten, Sozialpädagogik.

13. Vygotsky, L., S., (1978), Mind in Society. The development of higher psychological processes. London. Cambridge, Harvard University Press.

14. Vukasović, A., (2001), Pedagogija, 7. izd. - Zagreb, Hrvatski katolički zbor "Mi".

15. Zovko, G., (1999), Invalidi i društvo. Studijski centar socijalnog rada Pravnog fakulteta, Sveučilište u Zagrebu. Revija za socijalnu politiku, Svezak 6, str. 2, 5 . 
Nusret Kepeš, $\mathrm{PhD}^{2}$

\section{MODELS OF WORKING WITH PEOPLE WITH DISABILITIES IN ORDER TO PREVENT MENTAL HEALTH ISSUES}

\section{Abstract}

One of the most important indicators of a civilized society is the formation of an enabling environment for social justice and care for people with disabilities.Attitude towards people with disabilities has changed along with the development of society and scientific knowledge. Sumerians (5000 yr. BC) attempted to help people with disabilities so they treated them with religious rituals in a way that the priest-doctor listened to patients, revealed sin, determined the sacrifice and applied a certain treatment. The success or failure of this therapy depended on the demons. Humanistic attitude towards people with disabilities was also present in ancient Egypt, where people with disabilities were under the special protection of Gods.

"In China, it was thought that the blind have developed memory and thinking, and some of the earliest representation of human rights can be found in the texts of the Indian Vedas. Ideas of dignity, freedom, equality and justice occur even in Greek philosophy "(Zovko, 1999: 5). From the Stone Age (XIII to IV millennium $B C$ ) until today, the negative attitude of society towards people with disabilities is slowly changing. According to the Russian psychologist Vygotsky (1978), this attitude is defined by the social and historical context which can be divided into three periods. Historically, many dilemmas about the causes of diseases have been solved through these three periods and persons with disabilities have achieved partial rigths.

However, there still exist negative behavior and attitudes of community that are directed towards people with disabilities and the denial of their right to equal participation in all aspects of social life. Therefore, we can rightly say that, apart from prejudice and stereotypes towards people with disabilities, there is also present a level of discrimination.

Keywords: inclusion, mystical period, asylum period and the period of social integration.

${ }^{2}$ Islamic Pedagogical Faculty in Bihac. 


\section{الأستاذة الدكتورة نصرتا كيبيش”}

\section{أساليب العمل مع الأشخاص المعاقين بهدف وقاية الصحة النفسية}

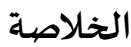

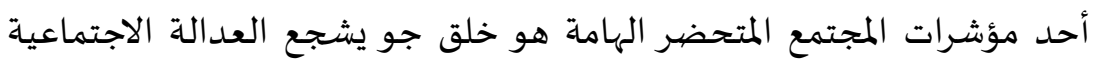

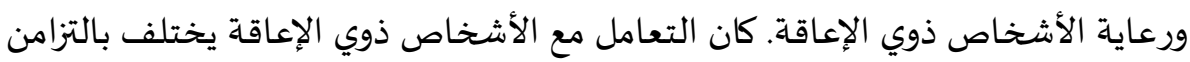

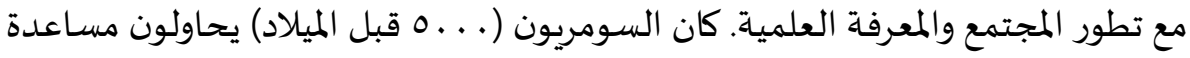

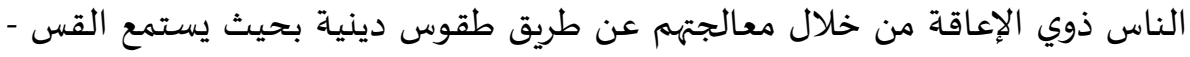

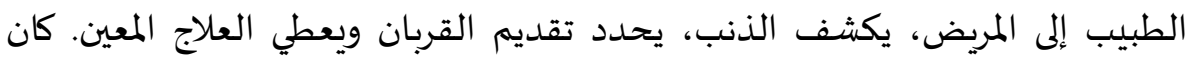

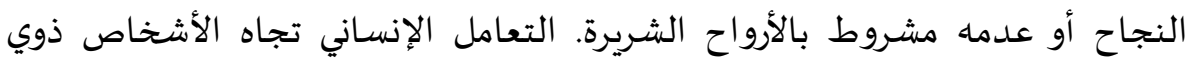

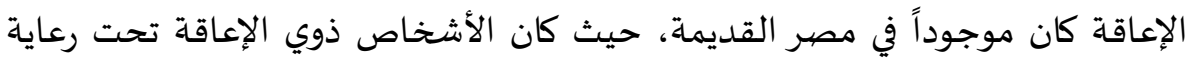

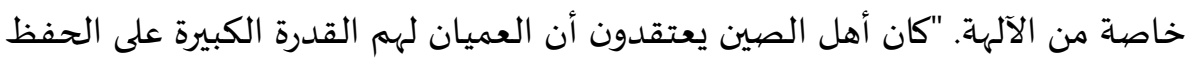

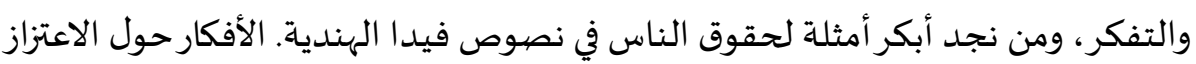

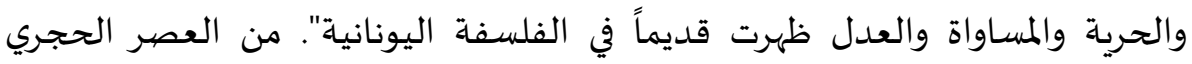

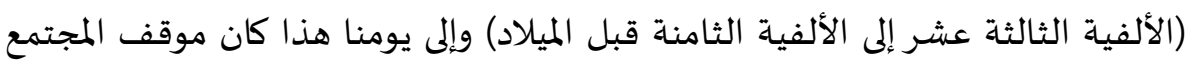

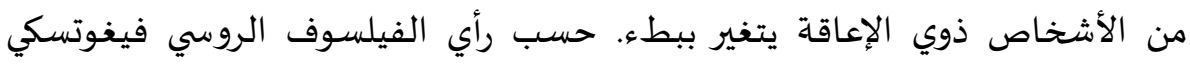
(I9VA)

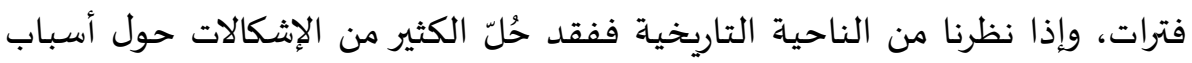

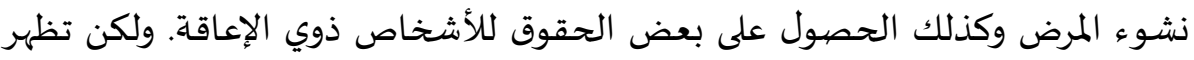

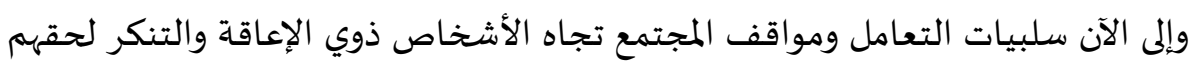

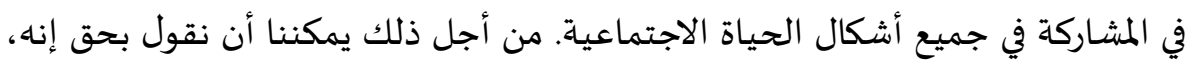

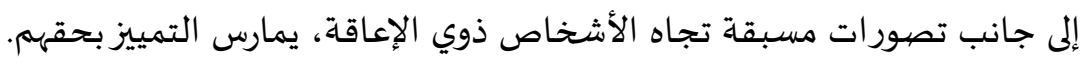

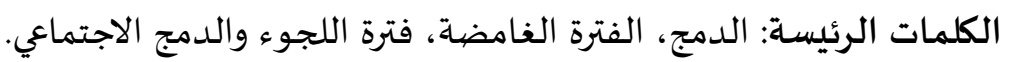

' كلية التربية الإسلامية بجامعة بهاتش 